\title{
Remembering for our Future: Affirming the Religious Education Tradition as a Guide for the Religious Education Movement
}

\author{
Harold D. Horell ${ }^{D}$ \\ Graduate School of Religion and Religious Education, Fordham University, Bronx, NY 10458-9993, USA; \\ horell@fordham.edu
}

Received: 29 November 2018; Accepted: 5 December 2018; Published: 10 December 2018

\begin{abstract}
This article addresses doubts about the viability, and hence future, of religious education. The researcher utilized structural analysis based on the questions: What central concepts and commitments have provided structure for the field of religious education as it has developed over time? How have social and cultural factors and changes in social and cultural context shaped the ways the structuring concepts and commitments of religious education have been embraced? To what extent can an understanding of the structuring concepts and commitments of the field enable us to make sense of the contemporary doubts about religious education? Additionally, the methodology of field mapping was used to map the models and approaches to religious education that have developed over time. The researcher found, and these findings are presented in this article, that structural analysis informed by field mapping can enable us to understand both the strengths and limitations of contemporary religious education. The researcher concluded that, based on a structural analysis of the field, religious educators can and should respond to the present crisis in religious education by defining the purpose and scope of religious education more clearly. The analysis in the final section of this article is based on that conclusion.
\end{abstract}

Keywords: religious education; history of religious education; religion and education; religious education and practical theology

"Memories are the key not to the past, but to the future" (Ten Boom 2009, p. 17).

\section{Introduction}

"What is the future of religious education?" I have encountered this question many times over the years. The first was when a senior scholar asked it at the 1996 meeting of the Association of Professors and Researchers of Religious Education (APPRE) in New Orleans. New members of APPRE were told we could "push the boundaries" and help carry the religious education movement forward by asking the question. (A focus on the future of religious education has been a perennial theme from the early days of the religious education movement to the present (see, for example, (King 1909; Tracy et al. 1917; Hartshorne 1933; McKibben 1939; Chave 1950; Vieth 1964; Fletcher 1968; Fahs 1971; Miller 1977; Hull 1982; Nelson 1984; Spiro 1984; Buckley 1991; Prevost 1998; Lee 2000; Groome and Horell 2003; Hull 2003; and Seymour 2005)).

Alternatively, "Is there a future for religious education?" "Does the field have a future or will it be replaced?" (O'Gorman 2015, p. 488). I have also periodically encountered questions such as these. Those doing the asking have expressed genuine doubts about the future of religious education. They have also pointed to such things as: children's religious education being replaced by children's ministry/spirituality programs and youth ministry, or being absorbed into general pastoral ministry in some congregations; the loss of volunteer religious educators, especially women in both Protestant 
and Catholic religious communities; the fewer professionally trained religious educators leading parish/congregational religious education programs and teaching religion in grade and high school settings; less of an emphasis on educating people to carry their faith into public life and the global community in some religious education programs; the decline in the number of academic degree programs and academic positions in religious education in recent decades; the absorption of academic degree programs in religious education into programs in practical theology or theology/religious studies and practice; and a loss of a sense of identity in the field of religious education. (Many of the reasons for raising doubts about the future of religion were explored by $\left(\mathrm{O}^{\prime}\right.$ Gorman 2015; Foster 2015; and Gilmour 2015).)

In this article, I provide an overview of the history of the religious education movement to show how a concern for carrying the religious education movement forward into the future has been central to religious education. Then, I discuss how, ironically, this concern for the future is connected to questions and doubts about the future of religious education. I conclude by discussing how religious educators can address these questions and doubts.

\section{The Emergence of Religious Education}

\subsection{The Beginning of the Movement}

The founding of the Religious Education Association (REA) was a boldly imaginative venture. In 1902, when William Rainey Harper issued a "Call for a Convention to Effect a National Organization for the Improvement of Religious and Moral Education Through the Sunday School and Other Agencies," he brought together scholars and practitioners with a variety of academic and pastoral/practical interests (REA Archives n.d.). He focused the efforts of this group on three overlapping, future-oriented aims. First, the most pressing reason for founding a new organization was the improvement of Sunday Schools, which were central to the educational ministry of Protestant congregations in the United States at that time. Second, on a broader level, the Call drew attention to inadequacies in religious and moral education and the need for its improvement not only in congregations but in homes, public schools, and other agencies. Third, Harper's Call was an appeal for scholars from educational and religious/theological/biblical fields of study to work collaboratively to generate research to guide religious and moral instruction in a more intentional and academically rigorous manner. This aspect of the Call led over time to the emergence of religious education as an academic field of study. Overall, through their efforts to improve religious and moral education within and beyond Sunday Schools, Harper and the other founders of the REA launched a future-oriented movement, the goal of which was the transformation of both religious communities and society (REA 1903, pp. 237-39). A deeper understanding of the religious education movement can be gained by looking more fully at each of its primary aims.

\subsubsection{Improving the Sunday School and the Educational Ministries of Religious Communities}

In discussing the scope and purpose of the REA in his address at the organization's first convention, Harper stated that the Sunday School "deserves all the emphasis that can be placed upon it" (REA 1903, p. 234). However, Harper offered a distinctly different approach for the "improvement" of the Sunday School than previous reform efforts. (For a discussion of the educational aims of the Sunday School in the United States and the periodic efforts to reform the Sunday School movement, see (Lynn and Wright 1980).) Harper did not call for the development of new Sunday School lessons or ways of teaching Christian doctrine. Rather, he called for a broader focus "on the part which religion should perform in the development of the individual and of society" (REA 1903, p. 237, emphasis added). Additionally, in his address at the first annual convention of the REA, John Dewey affirmed that the new organization should strive to foster religious growth, broadly conceived (REA 1903, pp. 60-67). Hence, the new organization was the Religious Education Association and not the Christian Education Association, and its focus was on religious and moral education rather than the teaching of Christian faith. 
In striving to understand the founding vision of the REA, it is helpful to think about methods of critical biblical interpretation in relation to the way Harper (who was a biblical scholar) and the other founders of the REA proposed to improve religious and moral education. Critical biblical scholarship is based on the premise that a person can gain a fuller understanding of biblical texts by first stepping back from their use in pastoral life and looking at them from a critically reflective perspective-for example, exploring biblical texts in the original languages in which they were written, and looking at when and why they were written and how they have been used throughout Christian history. Informed by this critical study, people can then step back into the pastoral life of the church and look at how biblical texts relate to present-day Christian personal and communal living.

Similarly, the founders of the REA called those concerned with the educational ministry of the Christian churches to step back from Sunday School instruction and to adopt a broader focus on religious and moral instruction/education. As Harper envisioned the REA in his address at its first convention, the organization would strive to foster new modes of academic research at the intersection of religion and education. In doing so, Harper suggested it "will undertake to render service in unifying" the insights of educational psychologists focusing on human growth and development, philosophers of education, curriculum and pedagogical theorists, biblical scholars, theologians, and others whose work shed light on processes of personal and social maturation and development, including and culminating with religious development. Informed by a fuller understanding of religious and moral development and approaches to fostering such development, those interested in the educational ministry of the Christian church would then be equipped to step back into the pastoral arena and work to improve the quality of instruction offered in Sunday Schools and other religious education settings (REA 1903, pp. 231-32).

\subsubsection{A Broad Focus on Religious and Moral Education}

Harper's Call to found a new organization to focus on religious education included, as already noted, an appeal to go beyond the Sunday School and to adopt a broad focus on the improvement of religious and moral instruction in other agencies as well. In his address at the first convention, Harper identified these other agencies as denominational/private and common/public schools, training schools, universities, colleges, seminaries, churches, religious organizations, homes, the press, and educational organizations and groups concerned with religious art and music (REA 1903, p. 234). At the founding convention, there were specific sessions on religious and moral instruction through the home, public schools, and Christians Associations and Young People Societies (REA 1903, pp. 108-72).

At the REA's first annual convention, George Albert Coe further expanded the Call's appeal for the new organization to have a broad focus. Coe argued that the REA should not begin with a "fixed system of religion," but should instead locate itself within "the modern educational movement" (REA 1903 , p. 45). As such, according to Coe, religious educators should begin with the premise that "the child is a living organism" and should focus on bringing out the child's "normal powers in their own natural order" within the various educational agencies found in the church and society (REA 1903, p. 45). Additionally, according to Coe "the child has a religious nature" and "religion is an essential factor of the human personality" (REA 1903, pp. 45, 47). Hence, a truly holistic educational process would include a focus on the religious development or education of the child. In fact, according to Coe, a focus on religious development "transfigures the whole idea of education" and can lead us to see that "religious education alone takes account to the whole personality" (REA 1903, p. 49). Coe challenged the members of the new organization to bring a focus on religious education into general education and, ultimately, to seek the transformation of society through efforts to promote full human development that culminates with religious development (REA 1903, pp. 50-51).

Coe further developed his understanding of religious education in his major works. In his (Coe 1916) The Psychology of Religion, Coe envisioned the religious aspects of religious education in terms of "the religious freeing of the individual and the righteous reconstruction of society" as "tending to fuse into one process" (p. 146). In his (Coe 1919) A Social Theory of Religious Education, 
Coe contended that "Society is not merely one educator among many; it is the primary educator within all educational enterprises" (p. 14). Based on a realistic assessment of social ills, Coe argued that, if we can "remove the limitations" that cause poverty and other forms of human misery so as to enlarge people's "social horizons," we can enable them to develop more fully as religious and moral persons in society (pp. 54-55). Throughout the first half of the twentieth century, Coe's work shaped the broad, future-oriented vision of religious and moral education at the heart of the REA and the field of religious education.

\subsubsection{Creating the Academic Field of Religious Education}

The first REA annual meeting not only established a new organization; it also created a new academic field of study - the field of religious education. From its beginning, the REA has been committed to encouraging research at the intersection of the fields of religious studies/theology and education that could improve the efforts of religious education practitioners. In looking to the future, REA's founders envisioned scholars in the various subfields of religious studies/theology and education (such as biblical studies, the philosophy of education, curriculum and instruction, educational psychology, social ethics, Christian ethics, and higher education administration) making contributions to research in religious education.

A tipping point in the further development of religious education as a field of study was reached in 1909. At this time, George Albert Coe left Northwestern University in Evanston, Illinois, where he was a professor of philosophy, and moved to Union Theological Seminary in New York to become "the Skinner and McAlpin Professor of Practical Theology and Director of the Department of Religious Education." In the same year, Coe became the seventh President of the REA. Coe was the first President of the REA who did not just have an interest in issues of religion and education; he was a religious educator teaching courses in religious education (Archibald n.d.). In subsequent years, other institutions of higher education also began to embrace religious education as a field of academic inquiry. For instance, Luther Weigle was appointed the first Horace Bushnell Professor of Christian Nurture at Yale Divinity School (YDS) in 1916. At YDS, Weigle taught courses and mentored doctoral students in religion education (Kathan n.d.). George Herbert Betts left a faculty position in psychology at Cornell College in Iowa to serve as a Visiting Professor in Religious Education at Boston University during the 1918/1919 academic year. He then become a Professor of Religious Education at Northwestern University (W. A. Smith n.d.). As the field of religious education continued to develop, there were more researchers who identified their primary area of specialization as religious education, more academic position in religious education, and more academic courses and programs in the field.

The field of religious education further developed in the 1950s. At that time, researchers in religious education working in academic settings began to meet as the Professors and Researchers Section of the Division of Christian Education of the National Council of Churches. In 1970, this group formed the Association of Professors and Researchers in Religious Education (APRRE) (Melchert and Litchfield n.d.). Then, in 2003, REA and APRRE merged to form the Religious Education Association, an Association of Professor, Practitioners, and Researchers in Religious Education (REA:APPRRE) (REA a n.d.). From that time to the present, REA/APPRRE has sought to balance foci on practice and research as the twin pillars of the field of religious education. That is, the organization has sought, as shown for instance in many of its annual meeting themes, to focus on present-day, pressing pastoral and social issues, and to explore how religious/theological and educational research can address these issues and lead religious communities and society outward toward a better future.

\subsection{The Religious Education Movement as Interreligious and Ecumenical, Inclusive, and International in its Early Development}

To understand the religious education movement, it is also important to recognize that the REA has always focused on outreach. The REA founders were primarily North American, white, male, mainline Protestants. Their outlooks were often marked by the sexist, prejudicial, and religiously 
sectarian outlooks on life of the time in which they lived. However, as they looked to the future, REA's founders considered how the religious education movement could become ecumenical and interreligious, inclusive, and international. As a result, and as discussed more fully below, the range of Christian voices within the REA and the religious education movement has increased over time. Additionally, Jewish religious educators were invited to join the REA when it was founded, articles written by Jewish authors have appeared regularly in the journal Religious Education from 1911 onwards, and while the REA's membership has remained predominantly Christian, Jewish religious educators have made significant contribution to the organization and the field of religious education (see Schmidt 1983, p. 53, note 76 ).

Intentional efforts to reach out to women also expanded the REA and the field of religious education (see Schmidt 1983, pp. 41, 46, 95). A tipping point was reached in 1972, when Ann Ida Gannon became the first women to serve as President of the REA and Iris V. Cully became the first woman President of APRRE (REA $b$ n.d.). Similarly, intentional efforts to reach out to people of diverse racial and ethnic background have over the years expanded the REA and the field of religious education (see Schmidt 1983, pp. 45-46, 92-93, 95). As a result, there has been greater racial diversity within REA and REA:APPRRE in the past fifty years, and in recent times the REA:APPRRE annual meetings have included work group sessions devoted to exploring religious education and the black experience, and the concerns of Asians and Asian North American Religious Educators (REA c n.d.). While there is still more that needs to be done to encourage racial and ethnic inclusivity, many REA:APPRRE members are committed to addressing racial and ethnic divisions, discrimination, and oppression, and raciallyand/or ethnically-motivated violence.

Internationally, the term Religionspädagogok (religious education) came into use in Germany in the early twentieth century as those concerned with education in the Christian religion in schools in that country sought to move beyond a catechetical approach to fostering Christian belief and adopted educational approached based on "current educational and psychological theories" (Osmer and Schweitzer 2003, p. 99). Then, the English term "religious education" migrated from the United States to Great Britain some forty years after the founding of the REA (Moran 2000, p. 136). Over time, the centuries-old traditions of religious instruction and education in faith in school settings, parishes/congregations, and families found throughout Europe and United States melded together in the international religious education movement. Moreover, throughout Europe, the religious education movement has spawned numerous organizations to nurture the ongoing development of efforts to educate in faith, most notably the International Seminar on Religious Education and Values, founded in 1978 (ISREV n.d.). At the present time, the small yet significant number of religious educators from beyond North America who are members of REA:APPRRE, attend its annual meetings, and serve in leadership positions within the organization, including religious educators from Muslim and other religious communities, have increased the organization's educational and religious outlook and activities. Additionally, there is now a network of international journals that publish articles in religious education, including Religious Education, The British Journal of Religious Education, The Journal of Belief and Values, The International Journal of Christianity and Education, The Journal of Religious Education (Australian Catholic University), The Journal of Christian Education in Korea, The International Journal of Children's Spirituality, Religion, Teaching Theology and Religion, and The Journal of Adult Theological Education. There are also established scholars, organizations, and programs in religious education in Turkey, South Korea, the Philippines, Australia, and other countries, and connections among religious educators around the world.

\subsection{The Social Context Shaping the Founding Imagination of the Religious Education Movement: Religious Education in the Age of the First Skyscrapers}

To understand the social dynamics that shaped the religious education movement and its development during its first half century, it is essential to consider its social context. The period from the end of the nineteenth century through the first two decades of the twentieth century was time 
of great optimism. This was an era of great economic growth throughout the world, the expansion of railroads, new scientific discoveries, and advancements in technology including those that led to the building of the first skyscrapers. Progressive social activists and political reformers confidently sought to alleviate and even eliminate social ills due to poverty and lack of social opportunities and began to address racism and sexism in society. On the religious front, the World Parliament of Religions was held at the 1893 World's Fair in Chicago. It generated interest in inter-religious dialogue and optimism about expanding religious understanding so as to enrich people's views about life and the world. (For a discussion of the development of an expansive sense of religion in the United States in the early twentieth century, see (Ahlstrom 2004, pp. 1037-54.)) Educationally, beginning in the mid-nineteenth century the United States invested heavily in education, including the education of children and youth, higher education, and various forms of ongoing education. Within and beyond the United States, education was seen as the engine of personal development and social progress. (For a discussion of the United States social investment in education during this era, see (Bankston and Caldas 2009).)

The founding members and leaders of the REA during its first half century were liberal religious educators whose theological outlooks were grounded in liberal theology and a socially progressive and optimistic outlook. They sought to bring the prevailing spirit of social optimism and the social advancements of that age more fully into the Christian churches to transform the Sunday School and other processes of moral and religious education. (For a discussion of liberal theology, see (Ahlstrom 2004, pp. 763-84). For a reflection on how liberal theology and progressive education shaped religious education, see (Boys 1989a, pp. 44-50).) Votaw (1905) offered one of the clearest articulations of the founding liberal vision of religious education. In addition to Coe's works, the classic texts of liberal religious education are, arguably Can Religious Education Be Christian? (Elliot 1940) and Today's Children and Yesterday's Heritage (Fahs 1952), while Social Principles of Education (Betts 1912); The Curriculum of Religious Education (Bower 1925); Liberal Christianity and Religious Education (Case 1924); and A Functional Approach to Religious Education (Chave 1947) are also important. Additionally, some of the theologians and ministers involved in the Social Gospel movement were drawn into the religious education movement, and many religious educators were inspired by the Social Gospel emphasis on social salvation and efforts to show how a Christian understanding of respect for persons could inform and perhaps even transform efforts to address social ills. (On the social gospel movement, see (Ahlstrom 2004, pp. 785-804).) Overall, the progressive spirit of the times was at the heart of the future-oriented imagination of the religious education movement.

\section{The Christian Education Era of the Religious Education Movement}

From the beginning, some religious educators did not support liberal religious educators' efforts to nurture religious development by focusing on natural religious growth. Many if not most of these religious educators emphasized how Christian faith shapes religious experience in distinctive ways. For example, in his first and influential book The Pupil and the Teacher Luther Weigle (1911) argued that natural religious growth is important but not sufficient, and that religious educators must be ready to guide adolescents when they reach the point of making a "decision" for or against God, a decision that for Christians involves recognizing human dependence on God and then turning to Jesus as the "Master Teacher" or "Ideal Teacher" (p. 196). Through the influence of Weigle and like-minded religious educators, there was a shift in emphasis in the religious education movement, and the movement moved into the Christian education era of religious education.

A sense of religious education in the first part of the Christian education era can be gained by reviewing a few of the major theorists. H. Shelton Smith's (Smith 1941) Faith and Nature catalyzed the turn away from the use of the term religious education and toward Christian education. Smith provided a sustained critique of liberal religious education and offered an alternative vision based on an understanding of the human person "in Christian perspective" (p. 67). The most influential book, perhaps, in the turn away from liberal religious education and toward Christian education was Randolph Crump Miller's (Miller 1950) The Clue to Christian Education. Miller's central claim was that 
"Theology must be prior to the curriculum!" (p. 5), and that "Christian nurture" must be based on "the relevant truths of Christianity" (p. 15). In Christian Education in a Democracy, Frank E. Gaebelein (1951) emphasized the importance of the Bible in Christian education and criticized liberal religious educators for not grounding their theological perspectives in the fundamental doctrines contained in the Gospel. Finally, one of the most compelling accounts of a Christian education understanding of religious experience is found in Lewis Joseph Sherrill's (Sherrill 1955) The Gift of Power. Sherrill contended that an honest assessment of the human condition will lead humans to confront deep-seated existential anxieties about the ability of the human self to cope with our finite and fallible nature as human beings. He then argued that religious experiences can lead us to be open to going beyond the self to encounter the power of God as a life-transforming gift, which for Christians is experienced in and through a relationship with Christ.

Some of the early Christian educators focused on religious experience and development (see, for example, (Sherrill 1951)), and the last significant research report on religious experience and development sponsored by the REA was Research on Religious Development edited by Merton P. Strommen (1971). Moreover, from that time to the present, there has been ongoing research on religious experience that influenced the field of religious education, such as the investigations of the Religious Experience Research Unit founded by Alister Hardy in 1969 at Manchester College, Oxford and now located at the University of Wales, Lampeter. It produced such significant studies as Edward Robinson's The Original Vision: A Study of the Religious Experience of Childhood (Robinson 1983, but the book was first published in 1977). However, one of the most consequential effects of the Christian education movement was that it shifted the language of religious education. Religious educators moved away from discussing religion and began to focus on faith.

Beginning with C. Ellis Nelson's (Nelson 1967) Where Faith Begins, religious educators began to explore how faith (and Christian faith in particular) is nurtured within persons and communities within specific life contexts. This emphasis on faith was strengthened by the incorporation of James Fowler's research on stages of faith into the field of religious education (Fowler 1981). Research on Christian faith and human development was also spurred by the seminal work of James Loder. Rather than focusing on religious experience, Loder was interested in how "convictional experiences" contribute to human development, and he focused primarily on the dynamics or logic of Christian convictional experiences by means of which a person is made into a new creation in Christ through the Spirit (Loder 1981, 1998). Moreover, in the past seventy years some of the most significant research in religious education has focused on how faith development and faith formation in persons, schools, and faith communities can lead people to greater fullness of life and a better future. (For a small sampling of the significant work on education in faith from a Christian education perspective, see (Bowman 1985; Borgman 1997; Crain and Seymour 2003; Foster 2006; Foster 2012; Groome 2011; Ng 1992; Seymour et al. 1993)).

\subsection{Christian Education and the Founding Aims of the Religious Education Movement}

By the mid twentieth century, there were deep divisions between liberal religious educators and those who identified themselves as Christian educators. These were sparked initially by works such as Norman Egbert Richardson's (Richardson 1931) The Christ of the Classroom and Walter Scott Athearn's (Athearn 1932) The Minister and the Teacher. The divisions were then deepened by H. Shelton Smith's stark contrast between religious education and Christian education. (See, for example, (Smith 1942-1943).) However, the Christian education movement can be understood fully only when it is seen as being one aspect of the further development of the future-oriented, religious education movement.

\subsubsection{Improving the Educational Ministry of Religious Communities}

First, in continuity with the founding vision of the REA and as part of the ongoing development of the religious education movement, most Christian educators have sought to improve the educational ministry of the Christian churches by examining it from a critically reflective educational perspective. 
Similar to liberal religious educators, many Christian educators have eschewed a narrow focus on the transmission of established Christian doctrines or socialization into a Christian community. They have tended instead to emphasize how religious education in religious communities can be improved so that it engages all aspects of human personhood and opens out to both personal and social transformation. (There are many books in Christian education in which the importance of critically reflective teaching and learning are highlighted, for example (Blevins and Maddix 2010; Gangel 1983; Groome 1980; Lee 2013; Little 1983; Melchert 1998; Moore 1998; Tye 2000; Wyckoff 1961)).

Many Christian educators have drawn insight from seminal educational theorists, including Paulo Freire (2018), Bell Hooks (1994), and Maxine Greene (1995), to name but a few. Many of them have also worked collegially with religious educators who similar to Coe envisioned religious education as an educational discipline, such as James Michael Lee, who argued that religious education should be envisioned as the social science that investigates the religious dimensions of life with a focus on their educational implications, and as such is a specialized form of educational analysis (Lee 1971, 1973, 1985). Given their broad focus on the religious development of persons and society, Christian educators have also drawn insight from scholars who researched religious development from an educational perspective such as Ronald (Goldman [1964] 1968, 1970), David Elkind (1970), and Fritz Oser (Oser and Gmünder 1991). Additionally, they have utilized the work of seminal developmental theorists such as Erik Erikson [1963] (Erikson [1963] 1985), Robert Havighurst (Havighurst 1984; Levine and Havighurst 1984), Lawrence Kohlberg (1981), Carol Gilligan (2003), and Robert Kegan (1982, 1994).

Christian education theory and practice has also been shaped by ongoing dialogue with those who Kieran Scott has labeled reconceptualist religious educators, including most notably Maria Harris and Gabriel Moran (Scott 1984). The reconceptualists reject Miller's contention that theology is the key to religious education and attempt to go beyond Christian education by reconceptualizing religious education as a field that uses concepts such as imagination, revelation, contemplation, and paradox to develop a robust understanding of the complex and often polyvocal nature of religious experience. They contend that the primary emphasis of religious education should be educational, not theological, in that religious educators should focus on teaching about religions (that is, about how religious experience has been embodied in specific religious traditions) and teaching how to live religiously (that is, how to embrace a sense of religiousness intentionally and in the present in a way that leads person and communities outward to lifelong and life-wide learning). Maria Harris's (Harris 1987) Teaching and Religious Imagination, a paradigmatic example of a reconceptualist approach to religious education, was well received by Christian educators and other religious educators when it was published and has been an influential book in the field of religious education ever since. Harris' (1989) Fashion Me a People has been appropriated by the Christian education movement and is generally regarded as a classic work of Christian education on education in faith within Christian religious communities. (On reconceptualist religious education, see also (Harris and Moran 1998; Moran 1989; and O'Hare 1993).)

Overall, throughout the twentieth century, many Christian educators maintained a critically reflective and future-oriented educational perspective. Informed by the work of education-anchored religious educators such as James Michael Lee, seminal educational theorists and landmark studies in various aspects of human development, and the work of reconceptualist religious educators such as Moran and Harris, the Christian education movement included a focus on the ongoing development and improvement of education in faith in religious communities.

\subsubsection{The Broader Focus of Religious Education During and after the Christian Education Era}

Second, during the Christian education era and into the present religious educators carried forward the founding intent of the REA to focus on religious education throughout church and society by exploring issues concerning education in faith with children, youth, and young adults within and beyond religious communities, higher education (including campus ministry and service programs), and other organizations and agencies as well. (For examples of broadly conceived Christian education studies of children, see the recent works (Allen 2008; Lawson 2012; and Yust et al. 2005). For examples 
of broadly conceived Christian education studies concerning children, youth, and young adults, see (Moore and Wright 2008; and Strommen and Hardel 2000). For an example of a discussion of higher education from a Christian education perspective, see (Ostrander 2009). Ostrander was educated as a historian, but he has worked in higher education for many years and his book has had a significant influence in some Christian education circles.) From the Christian education era to the present religious educators also contributed to the theory and practice of teaching religion to children in school settings, and the development of religious education curricula to be used in such settings. (Many Catholic educators in North America have been especially interested in religious education or teaching religion in Catholic schools and the development of religious education curricular materials for use in school settings. See, for example, the intellectual biographies of Maria de la Cruz (Buckley n.d.), Francoise Darcy-Berube (Veverka n.d.) and Thomas H. Groome (Horell n.d.).) As the religious education movement became more international, the focus on teaching religion in school settings became more pronounced through the influence of religious educators such as Robert Jackson in Great Britain (see, for example, (Jackson 1997)) and Graham Rossiter in Australia (see, for example, (Crawford and Rossiter 2006)). In his work, Jackson has been an influential advocate for school religious education to have an interreligious focus. Beginning in the latter part of the twentieth century, Christian educators and other religious educators also offered significant studies of adult education and adult religious education (see, for example, (English 1998; Elias and Merriam 2005; Parent 2009; Regan 2002; and Tauber 2015)). As they did when focusing on congregational education, Christian educators drew insight from a broad range of resources in exploring issues concerning education and education in faith throughout church and society. In their efforts to articulate a holistic educational focus, during the second half of the twentieth century and into the present Christian educators and other religious educators have often used the language of "faith formation," "ministry," and "spiritual development" in their work.

Throughout the Christian education era, there was also interest in educating Christians to develop a sense of social responsibility informed by faith, including among religious educators who played a significant role in turning the gaze of Christian educators inward so that their outlooks were distinctively Christian. For instance, H. Shelton Smith was deeply interested in issues of social ethics. The last chapter of his Faith and Nature includes reflections on how nurturing a theocentric perspective can enable Christians to develop deeper insight into the place of human values in the social order (Smith 1941, pp. 173-202, especially pp. 201-2). Randolph Crump Miller maintained a focus on the importance of educating Christians to live their faith in society, and this social focus became more pronounced in his later work (Miller 1950, pp. 154-69; and Miller 1989, 1991). C. Ellis Nelson, who offers one of the fullest accounts of how congregations socialize members in Christian faith, always emphasized how education in Christian faith should be complemented by moral education, the formation of conscience, and the development of a critically reflective outlook toward both church and society (see, for example, (Nelson 1967, pp. 93, 102-20 and Nelson 1983)). Additionally, from the Christian education era to the present, there have been religious educators who highlighted the importance of educating people to examine pressing social issues in the light of their faith and to be critically reflective about the ways in which society educates and influences people's faith/religious outlooks (among the many significant works in this area are (Boys 1989b; Moore 1989; Moran 1996; O'Hare 1983; Parker 2006; Schipani 1988; Seymour et al. 1984). Schipani is in the field of pastoral care and counseling but has made important contributions to religious education). Even Christian educators who regarded moral education and education for social responsibility as secondary, tended to acknowledge that they remained an important part of the educational ministry of the church (see, for example, (Smart 1954, pp. 44-45)).

\subsubsection{The Ongoing Development of the Field of Religious Education}

Third, Christian educators have contributed significantly to the ongoing development of religious education as an academic field of study. Christian educators played central roles in the founding 
and development of APRRE, the merger of APRRE and the REA, and the ongoing evolution of REA:APPRRE. They have also further developed and expanded the field of religious education. For instance, seminal works that further developed the theory and practice of Christian education include Groome's (Groome 1980) Christian Religious Education, Mary Elizabeth Moore's (Moore 1983) Education for Continuity and Change, Robert Pazmiño (2008), Foundational Issues in Christian Education, and Anne Streaty Wimberly's (Wimberly 2005) Soul Stories: African American Christian Education. Both Groome and Moore used the term "Christian religious education," and their works showed how Christian education can be situated within the field of religious education as it has developed since the beginning of the twentieth century. Pazmiño demonstrated how Christian educators can develop a comprehensive outlook based on an understanding of the universally human, cultural, social, personal, psychological, historical, and educational foundations of Christian education. Groome, Moore, and Pazmiño all claimed that Christian educators should prepare Christians for both participation in their religious community and to live as Christians in the world. In her landmark work Soul Stories: African American Religious Education, Wimberly made a compelling case for a narrative approach to Christian education. Moreover, the corpus of Wimberly's work, as Yolanda Smith (Y. Y. Smith n.d.) pointed out, covers "a wide range of topics, including teaching across the life-span; ministry with children, youth, adults, and senior adults; spirituality and healing; communal care; music; African American Christian education; worship as a model of education and faith formation; environmental justice; cross-cultural connections; marriage enrichment; nurturing families; teaching for justice, liberation, and hope; and engaging African American communities through Christian education." Additionally, Groome has played a central role in inviting Catholic educators into the religious education movement and REA:APPRRE, while Pazmiño and Wimberly have played similar roles within the evangelical Christian and African-American communities, respectively.

Developments throughout the last half of the twentieth century into the present reveal that Christian educators have not focused only on socialization in faith within specific Christian communities. Instead, in accord with the founding vision of the religious education movement, they have been committed to advancing religious education as an academically rigorous, ecumenical, and interreligious field of study that brings together a wide range of resources from various fields of study in order to explore how processes of education in faith anchor people in specific religious communities while also orienting them toward the future and to seeking the fuller realization of their religious and moral values in both religious communities and society.

\subsection{The Further Development of the Inclusive Spirit of the Religious Education Movement throughout the Christian Education Era}

To understand fully the contribution of Christian educators to the further development of the inclusive spirit of the religious education movement, three additional facets of the Christian education era need to be explored, with the first of these requiring the lengthiest explanation. First, while the religious education movement was characterized from the beginning by its leaders' desire to be ecumenical and inclusive of diverse perspectives, it was not until the Christian education era that the field of religious education became truly ecumenical. In explaining why this was the case, we can begin with a statement form one of the early religious education scholars. In an effort to provide direction for the field of religious education in the United States, Clyde Votaw stated: "The genuine union of all who believe in religion and morality must be secured. It can be secured when each will recognize his [her] own fallibility, peculiarities, and limitations, will honestly try to understand the other, and will resolve to sink difference for the sake of achieving the higher unity and the higher good" (Votaw 1905, p. 351). In this statement, Votaw voiced the desire of many of the early leaders of the religious education movement to be open to dialogue. Votaw presumed that, to work together, religious educators must "sink," (that is, ignore or discount) differences. Votaw's perspective is grounded in the theologically liberal and socially progressive sprit of that time, which I have already discussed above. One difficulty 
the early religious educators encountered is that many Christians of that time were unwilling to ignore difference to achieve unity.

In fact, Christian groups had exerted great efforts in the preceding 400 years to define themselves by their differences. At the beginning of the Protestant Reformation, Luther and his followers defined their theological and pastoral outlook by highlighting how they differed from Catholics. As the Protestant Reformation developed, the various Protestant groups developed distinctive senses of identity by defining themselves in opposition to one another. Additionally, during the Counter-Reformation, Catholics leaders sought to nurture a distinctive sense of Catholic identity by emphasizing how Catholicism differed from Protestantism. (For a discussion of the origins and development of the differences that divided the Protestant groups and separated Protestants from Catholics, see (Johnson 1976, pp. 276-99).) Liberal theology, which provided the theological anchor for most of the early religious educators, developed in part as an effort to overcome destructive religious conflicts that developed among those with differing theological and pastoral approaches. Nevertheless, at the time of the founding of the REA, many Christians continued to think that theological and pastoral differences were important, and that they could not simply be set aside or ignored. For instance, Catholicism in the United States was influenced by the high social value placed on education in the first part of twentieth century. However, most Catholic educators in the United States did not become members of the REA during this time. Rather, Catholic educators formed their own educational associations, most notably the National Catholic Education Association, founded in 1904. Most Catholic educators were not comfortable with the liberal theological outlook of REA's founders, including the idea of "sinking difference for the sake of unity." (For a discussion of the origins of liberal theology as an effort to overcome theological differences and initial reactions against this effort, see the discussion of nineteenth century developments in theology that began with Schliermacher in (Johnson 1976, pp. 375-80)).

During the first four decades of the religious education movement, there was a shift in focus and religious educators moved away from efforts to "sink difference" and began to emphasize another aspect of the founding vision expressed above by Votaw, namely, a commitment to "honestly try to understand the other." However, religious educators came to recognize that, to engage in genuine dialogue, they needed to share rather than ignore differences. As religious educators discussed differences openly, they began to refer to their guild of scholars and practitioners as a "fellowship"-more fully, as a fellowship of people with diverse outlooks who shared a common commitment to advancing religious and moral instruction within their own religious communities and the broader society. Ernest Chavez expressed the new approach to dialogue when he stated: "People should see varying concepts and practices set in vivid contrasts so that thought is evoked and interest aroused." According to Chavez and other religious educators of this time, by placing differences in "vivid contrast" religious educators could stimulate critical and creative reflection that would be mutually enriching to all involved. This approach to dialogue can be called "dialogue across differences" (Chave 1944, pp. 227-28). (One of the fullest articulations of the value of dialogue across difference is found in (Elliott 1950).)

During the Christian education era, dialogue across differences came to focus on differences in theological perspective. Initially, these efforts tended to focus on differences between the theological perspectives of liberal religious educators and religious educators influenced by neo-Orthodox theology, and the dialogues often became somewhat adversarial in tone (Smith 1942-1943 and Bower 1942-1943). Many of the religious educators critiquing liberal religious education felt they had to push back strongly against theological constructs with which they disagreed that had influenced the field of religious education significantly. Over time, however, theological conversation in the field of religious education became more amiable, and a spirit of genuine openness and mutual respect and mutual learning came to prevail. As a result, the REA, APRRE and then REA:APPRRE became a hospitable environment for people of various theological perspectives, including many Catholic educators and some evangelical Christian educators. (For a discussion of Catholics and the religious education movement, see (Elias 2004). For a discussion of Evangelicals and the religious education movement, 
see (Lawson 2003).) By the end of the twentieth century, many religious education forums, such as REA:APPRRE annual meetings, had become spaces for professional development where Christians of diverse theological and ecclesial commitments could step back from their specific religious contexts and engage in dialogue that provided them with new insights to inform their work when they stepped back into their everyday life, work, and ministries.

Additionally, practical theology became the template or guide for ecumenical dialogue among Christian educators during the Christian education era. That is, while grounded in the theological outlooks of specific Christian denominations and/or approaches to theology (such as process or liberation theology), Christian educators have used the language of practical theology to dialogue across differences. The language of practical theology has also been used to articulate a shift in methodology that occurred when religious education moved into the Christian education era. The early religious educators sought to investigate religion, religious experience, and processes of religious education from a scientific, analytic, and critically distanced perspective. Christian educators have maintained a commitment to the rigorous, critically reflective analysis of religious, especially Christian, beliefs and educational processes. However, they have been more interested than religious educators of the preceding era in exploring how their specific Christian commitments influenced and should shape their religious educational outlooks. For many Christian educators, practical theology has provided a language for engaging in rigorous theological explorations that are grounded in phronesis, that is, deep wisdom or practical insight, nurtured by personal and communal Christian commitments. (A sense of the methodological shift that took place in the Christian education era can be gained by comparing the approach of (Starbuck 1909) with the practical theological approaches of (Groome 1987 and Fleischer 2000).) Additionally, because many European religious educators identify themselves as practical theologians, efforts to envision religious education as practical theology have contributed to the international development of the field.

A second development during the Christian education era that contributed to the further development of the inclusive spirit of the religious education movement was the deepening of a commitment to interreligious education from the mid-twentieth century to the present. Under the leadership of Herman Wornom, who served as the REA General Secretary from 1952 to 1970, there was an intentional effort to invite more Jewish educators to join the REA and to encourage greater dialogue between Jewish and Christian educators. A major focus of this dialogue was on how shared religious values provided common ground for Jews and Christians in the United States (Gunn 2018). Since 1970, there have been significant proposals for further developing interreligious education. (For examples of the many proposals offered, see (Boys et al. 1995; Browning 1990; Caldwell 2011; Court and Seymour 2015; Halsall and Roebben 2006; Selçuk 2018).) Overall, the inward turn to focus on the distinctiveness of Christian education, did not include a turn away from interreligious encounter. Rather, while anchoring their approaches in their Christian convictions, Christian educators have turned outward and engaged in both ecumenical and interreligious encounters as they have looked to the future and the further development of the field of religious education.

Third, during the Christian education era the field of religious education became more academically inclusive. As noted above, the founders of the field of religious education envisioned it as an interdisciplinary field of study located at the intersection of the disciplines of education and theology/religious studies. Some of the early religious educators also drew insights from other fields. For example, in his Social Principles of Education, George Betts (1912) showed how core concepts from the fields of psychology and sociology could inform religious educators' understandings of teaching methods. Then, beginning with Lewis Joseph Sherrill, religious educators began to draw insight more extensively from other fields of study in developing their understandings of education in faith. In his two major books, Sherrill $(1951,1955)$ built primarily upon core concepts of depth psychology in developing his understandings of religious development, encounter, and education. After Sherill, C. Ellis Nelson (1967) utilized resources from the fields of anthropology and sociology in laying the foundation for his approach to Christian education. Over time, some religious educators 
began to envision religious education as a cross-disciplinary or multidisciplinary, rather than an interdisciplinary, field of inquiry (see, for example, (Osmer 2000 and Osmer 2005, pp. 60-61, 307-308)). Today, a central though often unarticulated premise of many Christian educators is that, if their work has a secure anchoring in Christian faith, they can reach out and draw from a wide range of academic fields of study as they strive to understand the complex, multi-faceted dynamics of faith and education in Christian faith. Thus, even as Christian educators eschewed a broad focus on religious education and adopted a narrower focus on Christian education, they expanded the field of religious education.

\subsection{The Social Context and Theological Foundations of Religious Education during the Christian Education} Era: Religious Education in a Weary and War-Torn World

The social optimism firmly entrenched at the beginning of the twentieth century was shaken by the brutality of two world wars (1914-1918 and 1939-1945), the devastation caused by a world-wide economic depression (1929-1939) and the subsequent frequent failures of people around the world to respond compassionately to one another in situations of economic distress, the horrors of the Holocaust/Shoah (the genocide of approximately 6 million Jews from 1933 to 1945), and acts of racial violence and hatred directed at African Americans in the United States (ranging from lynchings and beatings to prejudicial treatment and the denial of civil rights, and which have marred the country since its founding, but that were especially bloody and destructive from 1915 to 1944 and then again from the early 1950s through the 1960s). Based on an awareness of these horrific events, some religious educators came to think that the liberal, progressive religious outlooks prevalent in their field were unrealistic, even naïve, and they began try to reshape the field of religious education (see, for example, (Richardson 1931 and Athearn 1932)). Then, in striving to renew the field of religious education, many Christian educators turned to neo-orthodox theology in search of insight. Neo-orthodoxy focuses on the Transcendence or Otherness of God, the distance between God and humanity, the pervasiveness of sin and its influence on society, and the need for redemption in Jesus Christ. The two neo-orthodox theologians who had the most influence on religious education at this time were Reinhold Niebuhr and Elmer Homrighausen. The first, R. Niebuhr, heightened awareness of the need to reshape religious education. The second, Homrighausen, was instrumental in showing how it could be reshaped.

As twentieth century Christians sought to make sense of the horrors of their world, one of the books that profoundly shaped the religious imagination was Moral Man and Immoral Society by theologian and Christian ethicist Reinhold Niebuhr (1932). Throughout the twentieth century this book was read by many (including many Christians, Jews, and secularists) as a compelling account of how the collective ego of social groups can lead organizations, institutions, and governments to act immorally, and how human beings can be led by an awareness of the prevalence of social immorality to recognize their need for and dependence on God. For religious educators, R. Niebuhr's critiques of the philosophy and educational approach of John Dewey and the optimism of the Social Gospel movement were especially challenging. (The contrast between R. Niebuhr's social stance and that of the liberal religious educators is shown clearly in (Coe and Niebuhr 1933). See also Boys' comments on the influence of both Neo-Orthodoxy and R. Niebuhr on Christian education (Boys 1989a, pp. 66-68).) Early Christians educators such as H. Shelton Smith, Lewis Sherrill, and James C. Smart built upon Niebuhr's analysis in critiquing the social optimism of liberal religious education and arguing that the field of religious education needed to be grounded in a distinctively Christian outlook on life.

Beginning in the third decades of the twentieth century the social and religious imagination of Christian educators was also shaped profoundly by the work of practical theologian and Christian educator Elmer G. Homrighausen, especially his book Christianity in America: A Crisis (Homrighausen 1936); see also (Homrighausen 1939). Homrighausen argued that liberal Christian educators had not provided a sufficient account of God's agency and had not shown how Christians could be educated to apprehend and appropriate a sense of God's active, guiding, and saving presence in human affairs. Homrighausen called religious educators to go beyond a sense of natural religiousness and explore how Christians could ground their understanding of religion in Christian faith, not as set of fixed 
beliefs but as a living religion that could lead them to develop a broad perspective grounded in a sense of the eternal and otherworldly and, at the same time, be focused on discerning how best to address personal and social issues within the concrete, existential circumstances of life. Although Miller did not reference Homrighausen, his The Clue to Christian Education echoed central ideas from Homrighausen's work, and these ideas have continued to echo within the field of religious education, including in discussions of religious education and practical theology.

The other social trend that had a significant impact during the twentieth century was globalization. During this century, people of differing backgrounds and diverse social, moral, and religious outlooks came into contact with one another more and more frequently. As Christians educators considered how they could address the sense of the complexity and social and moral diversity and ambiguity people experienced living in a global age, they could have turned even further inwards. More fully, the embrace of neo-Orthodoxy turned Christian educators inward to focus on the importance of nurturing a distinctively Christian outlook on life that could enable them to make sense of and respond to the foundation shaking and horrific event of the twentieth century mentioned above. Their embrace of neo-Orthodoxy could also have led them to adopt an exclusively countercultural outlook and to emphasize the contrast between the diversity and ambiguity of social, religious, and moral outlooks found in a global world and the security provided by an established and distinctively Christian outlook on life. However, as already discussed, seminal Christian educators such as H. Shelton Smith, Elmer Homrighausen, Randolph Crump Miller, C. Ellis Nelson, and James C. Smart did not retreat into Christian sectarianism. Rather, they affirmed the importance of a distinctively Christian perspective, not as a retreat from the world, but as a foundation for engaging the world in all its complexity and ambiguity. Consequently, as Christian educators and religious educators responded to the currents of globalization, the field of religious education maintained an outward focus on educating people to bring their faith to bear on issues of public life and the global community.

Moreover, the religious education movement benefited from globalization. From the founding of the REA onwards, the religious education movement was committed to outreach, openness, and inclusivity-to overcoming racial, gender, religious, and geographical divides in order to encourage broad engagement among those interested in the intersection of religion and education. Such broad engagement was not truly possible until the currents of globalization eroded the barriers among people at local, regional, national, and international levels, and regular global communication and reliable means of global transportation became realities. Hence, the practice of dialoguing across differences in the field of religious education was enhanced by globalization.

At the dawn of the twenty-first century, it appeared to many that the field of religious education would flourish long into the future. The core commitments of the field continued to provide a guiding light for religious educators. The field had adapted to take into account the harsh social realities of the twentieth century. At the end of a century that left many feeling a bit frayed, religious education offered a hope-filled outlook on life.

\section{The Era of Uncertainly in the Religious Education Movement}

The positive, hopeful spirit in religious education that existed at the beginning of the twenty-first century has not lasted. Rather, we have entered a new era, an era of uncertainly. Today, there are many within and beyond the field of religious education who have raised serious doubts about its continued viability, with one senior scholar asking, as already noted: "Does the field have a future or will it be replaced?" (O'Gorman 2015, p. 488). The question to ask is: What has happened to or within the field of religious education that has led people to doubt its future?

\subsection{The Religious Education Movement Mentality: A Strength and a Limitation}

I suggest that in considering the uncertainty in religious education we reflect on the image that has guided the field from the founding of the REA to the present. As already noted, in his address at the founding convention of the REA, William Rainey Harper referred to religious education as a movement. 
Similarly, at that founding convention, George Albert Coe envisioned religious education as part of the "modern educational movement." Six years later in his presidential address to the REA, Coe (1910) spoke of the organization as a movement. Then, in his 1944 retrospect, Coe (1944) reaffirmed the image of religious education as a movement. In "A History of the Religious Education Association," Orville L. Davis (1949) also characterized religious education as a movement. In A History of the Religious Education Association, Stephen Schmidt (1983) suggested that, from the founding of the REA onwards, the best way to describe religious education was as a movement (p. 33). Characterization of religious education as a movement have continued from then to the present. For instance, in his review of the 100-year history of religious education, Allan J. Moore referred to religious education as a movement (Moore 2003, p. 143). A few years later, Randy Litchfield (2006) discussed the "research needed by religious education as a movement" (p. 165). In exploring differing ways of looking at religious education, Mai Anh Le Tran (2011) affirmed descriptions of religious education as a movement and discussed as a strength the "indecidability" or open-endedness that comes with being a movement (p. 160).

A movement is a group of people who come together based on a shared outlook and a commitment to address one or more pressing social issue. Movements are often spontaneous. They tend to lack established rules and procedures. The locus of identity in movements is external not internal. Movements tend to focus on pressing issues that a group wants to address, not on the development of internal, organizational structures. In fact, too great a focus on internal matters can hinder a movement. Movements need to be agile, open-ended, and adaptive. In a movement, where the group is heading is more important than where they came from.

When the REA was founded, the field of religious education was established as a movement to improve the religious and moral instruction in Sunday Schools and other agencies and organizations. As a movement, religious education has since then looked to the future to address pressing issues in church and society concerning religion and education. In the first part of the twentieth century the religious education movement looked to the future and envisioned how religious and moral education could be improved by incorporating modern, progressive pedagogies, insights from educational psychology, a sensitivity to ecumenical and interreligious issues, a spirit of openness and inclusivity in addressing issues of ethnicity, race, and gender, and new theological understandings from liberal and Social Gospel theologies that resonated with the spirit of the time. By mid-century, the movement, now led by Christian educators, was looking to the future and imagining how religious and moral education could be improved if it were more deeply grounded in distinctively Christian perspectives. At the beginning of the twenty-first century, as Le Tran noted, the religious education movement continued to look to the future. It continued to adapt approaches to educating in faith to changing times and the religious educational needs and interests found in a variety of contexts.

Le Tran highlighted how the field of religious education is marked by an "embrace of multiplicity" because religious educators have developed an "impressive variety of multimodal, multi-faceted teaching/learning approaches" as they have shaped religious education over time in a wide variety of contexts (pp. 150,156). Le Tran concluded that the field of religious education is "limitless" and "inviting" (p. 161). Based on the analysis provided above, we can affirm Le Tran's claim that the flexibility that has come with being a movement has been a great strength of the field of religious education. The movement mentality prevalent in religious education has enabled it to be open and adaptive and, as a result, to thrive throughout the twentieth century. As a movement, in the twenty-first century, the field of religious education has moved further into the flow of the currents of globalization with the hope of realizing its founding vision of becoming truly ecumenical, interreligious, international, and broadly inclusive. However, as already noted, this hope has been diminished by increasing doubts about the future of religious education.

I suggest that the open-ended, adaptive, and forward-looking nature of the religious education movement, while it has been a great strength, has also been a limitation that has contributed significantly to the present uncertainty in the field. Specifically, I suggest that religious education has been impoverished and as a result its future is now in doubt because its movement mentality 
has too often led those of us who are religious educators to forget the core commitments of, and the collective wisdom that has developed within, our field of study. My concerns about the limitations of the movement mentality that has guided religious education are based on forty years of professional experience in the field.

My first concern is that the movement mentality of the field has too often led those of us who are religious educators to forget, at times, the core, founding, commitment to adopt a broad focus on the religious dimensions of human personhood. While I have had this concern for almost two decades, it is illustrated by a recent experience. In a presentation at a professional meeting, two religious educators, one a Catholic educator and one an evangelical Christian educator, shared insightful new approaches for educating in faith that were designed to address the spiritual concerns of Millennial generation young adults in their denominations. Neither of these presentations considered the potential ecumenical and interreligious significance of the approaches presented. Neither was presented in a way that would encourage people of diverse religious perspectives to enter into dialogue with one another. In the discussion that followed the presentations, there was very little conversation about how the two approaches stood in relation to each other, and how a comparison of the two could help those present understand the religious dimensions of human personhood more fully. Rather, the discussion session was two separate conversations, each focused on what can be called denominational or ecclesial education, that is, education in faith within each of the religious communities being discussed.

I left that session thinking that we had forgotten William Rainey Harper's counsel at the founding convention of the REA. He urged those interested in improving education in faith in particular ecclesial settings to adopt a broad focus "on the part which religion should perform in the development of the individual and of society" (REA 1903, p. 237, emphasis added). From the founding days of the REA onward, a concern for religious education in faith communities has been central to the religious education movement. However, a core commitment of religious educators throughout the twentieth century was that they could best serve both church and society if they reflected on education in faith within specific ecclesial or denominational contexts from the perspective of a broad concern for the religious development of persons and communities-a concern guided by a spirit of openness and inclusivity, an ecumenical and interreligious sensitivity, and a commitment to exploring how educating in faith helps to equip people to live according to their religious convictions in their everyday lives. Experiences such as the one discussed here have made me wonder if this broad concern is now being lost, and if this loss contributes to the present uncertainty about the nature and purpose of religious education. As I have reflected on the experience just discussed, I have also wondered if the movement away from the language of "religion" to the language of "faith" contributed to the development of a tendency among those of us who are religious educators to forget, at times, the value of a bringing a broad and inclusive religious focus to our work. Now, the use of the language of faith enabled the religious education movement to continue to evolve, and the devotional study of religious faith in pastoral contexts is an important aspect of religious education. However, has an emphasis on faith also led in some instances to a loss of a distinctive focus on human beings as religious beings?

Second, I am also concerned that the movement mentality has too often led those of us who are religious educators to forget, at times, the core, founding, religious education commitment of our field to focus on the educational aspects of human personhood, and to consider how research in the field can contribute to the education of persons, within and beyond religious communities, for public life and participation in the global community. The underlying issue of this multi-faceted concern can be illustrated by another professional experience. I recently reviewed a religious education book proposal concerning a model for teaching religion in Catholic high schools. The proposal was informed by a nuanced reading of contemporary postmodern culture, and a deep understanding of the dynamics of adolescent social, emotional, and moral development. However, in discussing the teaching approach he was proposing, the author stated that he did not think the approach could be applied outside of Catholic schooling. As I read this comment, I thought of George Albert Coe who, as already noted, argued in his address at the organization's founding convention that the REA should not begin with a 
"fixed system of religion," but should instead locate itself within "the modern educational movement" (REA 1903, p. 45).

Coe and many religious educators who came after him, including many Christian educators, envisioned the field of religious education and the field of general education as having a common interest in bringing a critically reflective educational perspective to bear in addressing issues of educational theory and practice. Additionally, many religious educators as well as many general educators throughout the twentieth century were concerned with the holistic educational development of persons and communities. While religious educators have often worked within specific religious educational contexts and contributed to efforts to educate in faith in those contexts, they have envisioned their religious educational perspective as connecting with educational perspective beyond their specific ecclesial contexts.

The experience discussed above and other experiences I have had in the past two decades suggest to me that those of us who are religious educators may sometimes lack a fully developed sense of the educational aspects of religious education. I have wondered if developments in religious education in the second half of the twentieth century have contributed to this lack. As already noted, in their efforts to articulate holistic approaches to religious education many Christian educators began using language such as "formation," "faith development," "spiritual development," and "nurturing spirituality." This language enabled the religious education movement to adapt and move forward. However, as I have reflected on the incident discussed here and similar experiences I have wondered: Has a movement away from a clearly defined educational focus within the religious education movement led, in some instances, not to an expansion of the field but to a forgetfulness of its core educational commitments, a forgetfulness that has contributed to the development of the presents-day doubts about religious education?

Third, I am also concerned that the movement mentality of the field has too often led to a forgetfulness of the core, founding, religious education commitment to nurture the development of religious education as a distinctive field of academic study at the intersection of the religious studies/theology and education. Again, I can refer to recent professional experiences to illustrate this concern. In a meeting of religious educators a few years ago, one of my religious education colleagues identified herself as being in the field of congregational learning, while another stated that she was in the field of childhood religious development. As I reflected on these responses, it seemed to me that congregational learning and childhood religious development are, at best, emerging fields of study. They are certainly not fields of study in the same way that religious education is, and they are probably best thought of as specializations or subfields within religious education. In another instance, I have also heard a religious education colleague identify himself as being in the field of theological education, and I know many religious educators who identify themselves as practical theologian. Additionally, I once had a conversation with a young scholar, educated in the field of religious education and now a self-identified practical theologian, who argued that practical theologians educated in such fields as spirituality, contextual theology, or Christian ethics and who have a scholarly interest in how people are formed in faith can be considered to be religious educators-even if they have never taken a course in religious education or engaged in the academic study of seminal religious education theorists or practitioners. Finally, a few years ago I was part of a process that involved interviewing scholars who recently completed doctoral programs in which they specialized in religious education. All of these young scholars were able to articulate how a formational lens was central to their research. However, many of them were not able to discuss how a seminal twentieth century religious educator influenced the development of their professional outlook. Many of them were also not able to articulate how their research interests related to core concerns in the field of religious education as the field has developed from the early twentieth century to the present.

In the experiences recounted in the last paragraph there is a common factor, a forgetfulness of the field of religious education as a distinctive field of academic study. As I have reflected on this forgetfulness, I have wondered if its origins can be traced to the movement mentality in the field of 
religious education and the emergence and use of the term "Christian education" as a replacement for "religious education" in the mid-twentieth century. Hence, I have been led to ask: Has the movement away from the use of the term religious education diminished the core, founding commitment of the religious education movement to develop a distinctive field of academic study at the intersection of religious studies/theology and education? Has the future-oriented movement mentality led those of us who are religious educators to forget, at times, the core commitments and cumulative wisdom that has developed in the field over time and that today can provide a starting point for a variety of religious educational concerns, such as congregational learning and childhood religious development?

\subsection{Doubts about the Future of Religious Education in Pastoral Religious Education}

My concerns about the future of religious education go beyond the academic issues just discussed. I also suggest, based again primarily on my professional experience, that there has been a loss of a sense of the distinctiveness of pastoral religious education that parallels the forgetfulness of core commitments in religious education as an academic field of study. First, just as there has been a forgetfulness of a broad sense of the religious in the academic study of religious education, there is often today a loss of a broad sense of the religious in pastoral religious education. For instance, when religious education programs are replaced by ministry, spirituality, spiritual development, or faith formation programs, often times in my experience, the new, replacement programs have a narrower focus. They emphasize the teaching of the beliefs of a specific religious group (that is, they focus on denominational education), forming people to follow the practices of a specific religious group (that is, denominational socialization), and/or personal, internal faith development. While denominational education and socialization and personal faith formation are essential aspects of religious education, when they become the exclusive or even primary focus, a broader focus on the holistic religious development of persons and communities is often diminished. An emphasis on ecumenical and interreligious education is also sometimes lost. (Discussions about the Doctrinal Elements of a Curriculum Framework for the Development of Catechetical Materials for Young People of High School Age illustrate the narrowing of the focus of pastoral religious education in Catholic education (USCCB 2008). The introduction of Doctrinal Elements states that the purpose of Catholic catechesis is to lead people into intimate communion with Jesus Christ, that is, to nurture people religiously by guiding them to develop a deeper relationship with God as made known in Jesus through the Spirit. However, discussions leading up to the development of Doctrinal Elements and discussions about its use after it was published in 2008, have tended to emphasize the importance of knowledge of Catholic doctrine as a foundation for Catholic identity. There has not been a sustained broader focus in these discussions, at least the one's in which I have been involved, on nurturing the personal and communal religious development of Catholic Christians. It is also significant to note that that the curriculum framework in place before Doctrinal Elements included a focus on ecumenical and interreligious issues in the core curriculum. In Doctrinal Elements "Ecumenical and Interreligious Issues" is listed as the last of a number of electives.)

Second, just as in academic settings, when the focus on the religious become narrower in pastoral religious education, the emphasis on the educational also often becomes narrower. When pastoral religious education efforts focus on denominational education or socialization, there tends to be a lack of openness to educating people to appropriate faith traditions in a critically reflective way. When the focus of pastoral religious education is on the beliefs and practices of a religious community and the internal faith formation of members of that community, the importance of educating people to relate their faith to the concerns and challenges of their everyday lives tends to be deemphasized.

Third, just as there has been a forgetfulness of religious education as a distinctive field of academic study, there has been a corresponding loss of a sense of religious education as an important and distinctive field of pastoral practice. For instance, I know of Catholic parishes that once hired professional lay ecclesial ministers with master's degrees in religious education to oversee their education in faith programs that now rely on volunteers or paid staff without a background in 
religious education to lead these programs. In talking with pastors and other parish staff members about this issue I have been told, essentially, that when parish education in faith programs focus on denominational education or socialization or spiritual formation, there is no need for a professionally educated religious educator. Similarly, Catholic schools that once hired people with a master's degree in religious education to teach religion in their schools are today hiring people with a master's degree in theology. In my experience, the most common reason for doing so is that high school administrators sometimes think professionally educated religious educators do not have a distinctive expertise that would set them apart from someone with a master's degree in theology. Now, parishes/congregations and schools are different educational contexts. Most professionally educated religious educators are equipped to teach and lead religious educational efforts in both contexts. Today, however, the distinctive expertise that professionally educated religious educators could bring to either of these contexts is in many instances not recognized or not valued. (For discussions of the issues raised here from perspectives that are similar yet somewhat different than the perspective offered, see (Foster 2015, pp. 551-53 and O'Gorman 2015, pp. 562-64).)

\subsection{Charting the Future of Religious Education}

Mai-Ahn Le Tran, as already noted, envisioned the field of religious education as "limitless" and "inviting." Many of us who labor in the field of religious education share her assessment. However, if religious education, as a field of academic study and area of pastoral practice is to have a viable future, the difficulties concerning religious education discussed in the last two subsections must be addressed. How they are addressed is critically important. In accord with the future-oriented focus of religious education as a movement, one way of addressing these concerns is to approach them as issues that push the boundaries of religious education. From this perspective, we should strive to renew or refund the religious education imagination so that we can envision ways of guiding the religious education movement forward into the future that will resolve or take us beyond the present-day doubts about religious education. In my conversations with religious educators about how to address the current uncertainty in the field, this is often the strategy suggested. The movement mentality has been one of the greatest strengths of the field, and it is wise to try to continue to build upon this strength.

However, we also need to recognize that the movement mentality in religious education has contributed to the present uncertainty in the field. It has been a limitation as well as a strength. It has contributed to a forgetfulness of the core commitments of the religious education movement, and this forgetfulness has led people within and beyond the field to have a limited or distorted understanding of the nature, purpose, and distinctive identity of religious education. To counter this forgetfulness, I suggest that religious educators need to develop a backward-looking focus on the wisdom and insight that has developed within the field over time to balance the well-established forward-looking focus of religious education as a movement.

Additionally, because of the movement mentality in the field, religious education has a well-developed sense of an external locus of identity; its sense of identity is grounded in efforts to look outward and push the boundaries of existing theory and practice at the intersection of religion and education. Religious education has lacked an established sense of an internal locus of identity as shown, for example, by the continually shifting points of emphasis and language in the field. I suggest that this lack of an internal locus of identity has contributed to the development of doubts about religious education. It has even led some religious educators to try to find or create some other field of study that could provide an internal anchoring for their sense of professional identity, and it has led many people to fail to recognize that religious education is a field of study with a substantive core and distinctive focus. Religious educators could address this difficulty by drawing from the insight generated within the field of religious education since the founding of the REA to develop a sense of an internal locus of identity for the field.

I suggest that, if we are to overcome the forgetfulness in the field of religious education and address the difficulties it has generated, we must balance a sense of religious education as a tradition (that is, 
an established field of academic inquiry with a unique history and a distinctive vision for educating for fullness of life) with a sense of religious education as a movement (that contributes to the ongoing holistic development of persons and communities). Religious educators need to balance a commitment to conserving the religious education tradition with a commitment to advancing the religious education movement. How this can be done can be shown by a discussion of the following issues:

1. how to envision religious education in an academic context;

2. how we as religious educators identify ourselves;

3. the relationship between religious education and practical theology;

4. how we envision religious education as an educational field of study;

5. how we envision religious education as an interdisciplinary field of study; and

6. renewing the commitment within the religious education movement to dialogue across differences.

If we are to overcome the forgetfulness in the field of religious education, I suggest we clearly and consistently identify the field of study associated with the religious education movement as religious education, rather than Christian education, theological education, or as some other academic field. The religious education movement began with the founding of the REA in 1903, and the founders of the organization identified the field associated with the movement as religious education. As we strive to carry the religious education movement forward today, the best way to identify what we are carrying forward is to continue to name it as the field of religious education. The designation "religious education" is the most suitable name for connecting with and preserving the hundred-years-plus tradition of exploring the religious development of persons in religious communities and other institutions, organizations, and agencies that began with the founding of the REA.

Additionally, as we look back, we can note that the field of religious education has since its founding included a focus on the teaching ministry of the Christian churches beginning with the teaching of Jesus as presented in the gospels and extending to the contemporary teaching ministries of Christian churches. To preserve the religious education tradition, we should maintain this focus in the field of religious education today. However, as a forward-looking field of study, religious education has always included a focus on critical reflection and efforts to improve the teaching ministry of the Christian churches. To create a sense of separation between the critically reflective academic field of study they founded and the teaching ministry of the Christian churches, the founders of the REA named their new field of study "religious education," and not "church education" or "Christian education." Thus, to maintain a connection with the core, founding commitments of the REA, the best name for the field is religious education. As a forward-looking movement and field of study, religious education has also included a focus on moving outward to become more fully ecumenical, interreligious, and international. The most appropriate name for the field as an interreligious field is religious education. Moreover, the most descriptive name for master's and doctoral programs that focus on the religious education tradition and movement is, simply, Religious Education, rather than, again, Christian Education or Faith Formation or some other designation. When other designators are added to religious education, such as in programs in Religious Education and Faith Formation or Religious Education and Congregational Leadership, the names of the degrees could suggest that academic programs in religious education need to be augmented or supplemented to be viable. Hence, the singular designation "Religious Education" is the best name for such programs if we want to present them as programs in a generative field of academic study.

Once we identify the name of the field associated with the religious education tradition and movement, we need to identify ourselves as people who work within the field of religious education. To address this issue, I suggest that multiple designations are best. For instance, I identify myself as a Catholic educator and religious educator. Most of the founders of the REA were liberal Christian religious educators. As the religious education movement developed, it began to attract Jewish educators, evangelical Christian educators, Catholic educators, Muslim educators and those involved in education in other religious communities. During the first five decades of the religious education 
movement, religious educators learned that it was counterproductive to try to sink or ignore differences for the sake of unity. Rather, the movement advanced when religious educators spoke from the perspective of their grounding in specific religious communities and sought to learn from one another. They learned that by dialoging with one another they could gain new insights that could enhance their efforts to nurture the religious development of persons in their communities. Today, we can build upon the past and preserve the religious education tradition, if we continue to situate ourselves within our specific religious communities as Catholic education, Christian educators, evangelical Christian educators, Jewish educators, etc. while at the same time we also identify ourselves as scholars and practitioners who are religious educators united by a commitment to advancing the religious education movement.

The relationship between religious education and practical theology is another issue connected with the uncertainty in religious education today. Religious educators who teach in theology departments and seminaries can often relate more readily to their colleagues when they can articulate their professional interests as issues of practical theology. Additionally, as noted above, practical theology has become a significant methodology within religious education. However, because religion education as a field of study has lacked an internal locus of identity, it has been difficult for people within and beyond the field of religious education to articulate a coherent understanding of how to relate religious education to practical theology. Because religious education has been an outward looking movement focused on the scholarly exploration of issues at the intersection of religion and education, some academics have assumed that any scholar in theology or religious studies who has educational interests can be considered to be a religious educator. It has also been the case that religious educators who identify themselves as practical theologians have sometimes been unable to articulate how they, as religious educators, have a distinctive scholarly outlook that distinguishes them from practical theologians who are scholars in such fields as pastoral care and spirituality.

I suggest that those of us who are religious educators can bring a distinctive scholarly focus to discussions of practical theology and help to counter the present-day forgetfulness in our field, if we anchor our work in the religious education tradition. First, as the religious education tradition has developed it has gone beyond being a field at the intersection of religion and education. It has become a tradition with a hundred-year-plus history that is now global in its reach. By anchoring our work in the resources of this tradition, those of us who are religious educators can develop distinctive scholarly perspectives as religious educators. For instance, I had a recent conversation with a religious education doctoral student who is focusing her dissertation on religious education with homeless families in New York City. Her research has revealed that there are notable efforts by churches to offer social services, pastoral and spiritual care, and mental health counseling to the homeless women, men, and children who come to their churches. However, she also found that very few of these churches are equipped to respond to the deeper religious questions homeless persons raise, and they are often unable to provide effective support for homeless parents seeking to educate their children in faith. She proposes to develop religious education opportunities that could address these issues. In discussing her proposal, I suggested that she consider how she might draw insight from religious education theorists such as George Albert Coe, C. Ellis Nelson, Daniel Schipani, William Bean Kennedy, Letty Russell, Evelyn Parker, Thomas Groome, Allen Moore, and others as she strives to develop a distinctive religious education perspective for addressing issues of homelessness.

Second, there are identifiable core concerns in the field of religious education-such as concerns about nurturing the religious development of person in religious communities and other institutions, agencies, and organizations; exploring ways people can be educated to bring their religious convictions to bear in their everyday lives; educating for interreligious understanding; and considering, as Coe noted, how society educates, that is, how social situations and trends provide educational moments or opportunities. By anchoring their work in the core concerns of the religious education tradition and drawing insight from seminal religious education theorists, contemporary religious educators 
can develop distinctive scholarly perspectives, and help to address the current forgetfulness of these concerns found in the field today.

Paralleling concerns about the religious and theological dimensions of religious education there is another significant issue that contribute to uncertainly in the field: the issue of the educational foundations of religious education. As already discussed, at the time the religious education movement began in the early twentieth century education was a dominant social paradigm. Many people had great faith in the power of education to transform persons and communities. By the middle of that century, as people sought to make sense of the horrific events that had taken place in the prior four decades, people were much less optimistic about the efficacy of education. As people sought other conceptual paradigms to help them make sense of life, therapeutic and managerial modes of meaning became dominant. People began to think in terms of seeking therapeutic healing from the inevitable hardships they experienced and managing their lives as best they could. Religious educators adapted to the changing conceptual landscape by moving away from educational language; replacing it with foci on such things as faith formation, spiritual development, and the development of convictional experiences and commitments that could enable people to manage their lives despite whatever hardships they faced.

Therapeutic and managerial paradigms of meaning remain dominant in contemporary societies and educational perspectives are often overlooked, dismissed, or devalued. I was reminded of this aspect of the contemporary mindset in a recent conversation about the continuing crises of sexual abuse and accountability in the Roman Catholic Church. From the beginning of the conversation, the accepted presumption was that if we wanted to address the crisis we needed to focus primarily if not exclusively on care for victims/survivors of abuse and changing the managerial structures of the Roman Catholic Church so that issues of abuse were addressed more adequately. When I commented that we might also look at the issue as an educational moment in the life of the Church, my suggestion was dismissed by one person as being "off point" because it did not address "the issue of healing." Another person remarked that the only way to address the crisis adequately was to focus fully on the trauma experienced by victims/survivors of abuse. There were a few nods when I persisted and suggested that we also needed to focus on what we could learn from the crisis. However, in the discussion that followed, my conversation partners were unable to move beyond therapeutic and managerial foci, even though they sought to do so. For instance, in considering what we might learn from the crisis, one person commented that it raised issues of justice. She then noted, essentially, that as she thought about how unjust treatment by church leaders too often compounded the trauma of abuse, she lost confidence in the Church's ability to care for people and, when needed, encourage healing. Another person then responded with the suggestion that a greater focus on justice might lead to changes in the administrative structures of the church. My conversation partners were unable to envision how a focus on the justice issues raised by the crisis could lead us beyond concerns for therapeutic healing and with tinkering with the administrative structures of the Church and, from an educational perspective, prompt critical and creative reflection. If we had been able to adopt a critically reflective educational perspective, we might have been able to consider such questions as: How might the crisis lead us to pause and fundamentally reassess the extent to which the institutional church is guided by a genuine openness to God's guiding presence? In caring for victims/survivors of abuse, how might we listen and learn from them and ensure that their insights are included in efforts to re-envision or reimagine our ways of being church? How might the crisis help us to recognize the problematic aspects of the institutional Church that are leading so many people today to disaffiliate from institutional church membership? How could the Church as a social institution be fundamentally restructured so that it more truly and fully embraces its religious mission?

Therapeutic and managerial paradigms of meaning are valuable and important. Without them church and society would be less able to care for those in need and less equipped to deal with the difficulties of life and the complexities and ambiguities of contemporary societies and global, postmodern culture. However, these paradigms are not sufficient by themselves. We also need 
educational paradigms that can guide people to look beyond the present and imagine ways of moving past foci on pastoral care and managing life's difficulties so that they can learn from life and develop new ways of perceiving, reflecting, and engaging the world. Moreover, the religious education tradition provides significant resources to guide us in forging contemporary educational perspectives. These include, to name only a few, Coe's and Nelson's discussions of how society educates, Foster's work on event-full education, Groome's explorations of educating for life, Moran's emphasis on the importance of lifelong and life-wide education, and the discussions of education for hope in the works of Foster, Wimberly, and Parker. Additionally, as religious educators, we share a common commitment with many general educators to strive to foster growth toward greater fullness of life. Based on an understanding of this shared commitment, we should be open to exploring how dialogue with general educators could enrich our work, and how our work could possibly contribute to addressing issues in general education.

In considering the educational foundations of religious education, it is also important to remember that religious educators have used the language of faith formation to articulate paradigms of holistic religious education and to contribute to discussions about ministry development and formation in a variety of social and ecclesial contexts. Today, we should consider, I suggest, how continuing to use terminology such as "faith formation" and "spiritual development" can enable us to connect with the therapeutic and managerial paradigms prevalent in contemporary culture and contribute to discussions about faith formation in youth and young ministries and other areas of pastoral practice. However, I also suggest that as religious educators we should be especially attentive to ways we can use educational language in an intentional way to offer countercultural and challenging perspectives that invite people to move beyond the therapeutic and managerial mindsets prevalent in contemporary societies. Ultimately, as we invite people to question conventional modes of thought and action we should encourage them to consider how they can embrace more life-giving ways of being in the world. Additionally, in using educational language in an intentional way, religious educators can make distinctive contributions to academic discussions in religious studies/theology. That is, when we focus on educational development or look at issues with a focus on how they present learning opportunities. we can offer perspectives that complement the outlooks of scholars in such fields as pastoral care, spirituality, and systematic and historical theology but that also offer a unique angle of vision.

The issue of the educational foundations of religious education is related to another issue: whether religious education can and should go beyond being an interdisciplinary field at the intersection of religious studies/theology and education and be re-envisioned as a multi-disciplinary field so that it is better able to address the complexities and multi-faceted dimensions of contemporary life. The primary consideration in addressing this issue is a practical one. The fields of religious studies/theology and education are vast and contain many subfields. Individual religious educators can strive to gain a broad overview of these fields and then focus on drawing insight from one or more aspect of theology/religious studies and one or more aspect of studies in the field of education. To go beyond such a commitment to become truly multi-disciplinary scholars would be difficult, to say the least. For example, from its founding onwards, there has been a concern in the field of religious education with both religious and moral education. Religious educators who want to focus on moral education should attend to work done in the field of religious education on this topic. They might then turn outward and focus on moral theology and Christian ethics in theology/religious studies and studies of moral development in educational psychology. However, it could be difficult for a religious educator to develop a foundational knowledge of work in moral education in the field of religious education and studies of morality in moral theology, Christian ethics, and educational psychology, and keep abreast of current scholarship in these areas. It would be extraordinarily difficult to go beyond such a broad interdisciplinary focus and become a multi-disciplinary scholar who also has a foundational knowledge of studies on morality in moral philosophy, the fields of sociology and social work, and perhaps other academic fields as well, and then continue to stay abreast of current literature in these fields. 
In my experience, religious educators who strive to be multi-disciplinary scholars too often end up not anchoring their work in the religious education tradition and having a clear religious educational focus. For instance, in a religious education presentation a few years ago, the presenter drew insight from fascinating studies on mentoring in the fields of business psychology, leadership studies, sociology, and political science. In his presentation he identified himself as a multi-disciplinary scholar who had searched various field of study for research on mentoring. However, the presenter failed to draw insight from studies on mentoring in the field of religious education. He was unable after his presentation to articulate how his approach to mentoring was a religious educational approach. His scholarly outlook was marked by a forgetfulness of the core commitments of the field of religious education.

I suggest that, if we as religious educators are to anchor our approaches to scholarship and pastoral practice in the religious education tradition and carry the religious education movement forward, it is best to envision religious education as an interdisciplinary field of study, not a multi-disciplinary one. To present distinctive religious educational perspectives with clear religious and educational foci, we should ground our work in the religious education tradition and selected subfields in theology/religious studies and education. However, we should not ignore research in other fields of study that may be relevant to our scholarly interests. Rather, as Maureen O'Brien counselled, it is beneficial for us as religious educators to step back once in a while from our work, and place "ourselves at the margins of the many non-theological" (I add, and non-educational) "disciplines from which we can learn" (O'Brien 2010, p. 371). We can envision a willingness to step, occasionally, beyond a grounding in the religious education tradition and to walk the margins of non-theological and non-educational fields of study, as a future-oriented practice that can help to keep religious education as a movement open to new ideas and practices and moving forward. Additionally, in addressing particular issues from a religious educational perspective, it can be helpful to search for sources of insight across the academic disciplines AFTER developing a solid sense of how those issues have been addressed in religious education, theology/religious studies, and education.

Finally, to address the present-day uncertainties in the field of religious education, I suggest that religious educators must strive to renew the practice of dialoguing across differences and foster a sustained conversation about the future of religious education. As already discussed, the practice of dialoguing across differences in religious education developed in the early decades of the twentieth century and became central to the field by mid-century. It enabled religious educators who had differing perspectives to engage in mutually enriching conversations with one another. In the present era this practice has been somewhat diminished because of a greater focus in religious education on denominational education and faith formation in specific educational contexts. I suggest that if we are to make sense of the present uncertainty in the field of religious education, we need to renew the practice of dialoguing across difference and share with one another our differing ways of perceiving and reflecting on this uncertainty. Moreover, in considering such issues as how to make use of new information technologies in religious education, how to take into account the increasingly disaffiliation of many people. especially youth and young adults, from religious communities, and how to make sense of and respond to changing understandings of sexuality and gender, we as religious educators could benefit from a respectful sharing of diverse perspectives. Additionally, this article is written from a North American, mainline Christian church perspective. While I have not explored fully how traditions of Catholic education intersected the religious education movement, the article is informed by a Catholic perspective. The analysis offered is also shaped by my personal background and experiences. My hope is that the article provides a perspective for understanding the field of religious education and addressing the current uncertainties and doubts that plague it. However, I recognize that the perspective I offer is from a specific perspective and is thus limited. Hence, I invite readers to consider my analysis and then to enter into dialogue with me from their own points of view. I suggest that we need sustained dialogue across differences in the field of religious education today if we are to recognize and tap into the great potential in the field of religious education to continue to make significant contributions to scholarship and the pastoral life of the church. 
Conflicts of Interest: The author declares no conflict of interest.

\section{References}

Ahlstrom, Sydney E. 2004. A Religious History of the American People, 2nd ed. New Haven: Yale University Press. ISBN 9780300100129.

Allen, Holly Catterton, ed. 2008. Nurturing Children's Spirituality: Christian Perspectives and Best Practices. Eugen: Cascade. ISBN 9781556355585.

Archibald, Helen Allan. n.d. George Albert Coe. Christian Educators of the 20th Century. Available online: https:/ / www.biola.edu/talbot/ce20/database/george-albert-coe (accessed on 1 June 2018).

Athearn, Walter Scott. 1932. The Minister and the Teacher: An Interpretation of Current Trends in Christian Education. New York: Century.

Bankston, Carl L., and Stephen J. Caldas. 2009. Public education, America's Civil Religion: A Social History. New York: Teachers College Press. ISBN 9780807749470.

Betts, George Herbert. 1912. Social Principles of Education. New York: Charles Scribner's Sons.

Blevins, Dean, and Mark A. Maddix. 2010. Discovering Discipleship: Dynamics of Christian Education. Kansas City: Beacon Hill Press. ISBN 9780834124967.

Borgman, Dean. 1997. When Kumbaya is Not Enough: A Practical Theology for Youth Ministry. Peabody: Hendrickson. ISBN 1565632478.

Bower, William Clayton. 1925. The Curriculum of Religious Education. New York: Charles Scribner's Sons.

Bower, William Clayton. 1942-1943. Christian Education after Nineteen Centuries. Religion in Life 12: 41-47.

Bowman, Thea, ed. 1985. Families: Black and Catholic, Catholic and Black. Washington, DC: United States Catholic Conference of Bishops.

Boys, Mary C., ed. 1989a. Educating in Faith: Maps and Visions. San Francisco: Harper and Row. ISBN 0060610379.

Boys, Mary C., ed. 1989b. Education for Citizenship and Discipleship. New York: Pilgrim. ISBN 0829807969.

Boys, Mary C., Sara S. Lee, and Dorothy C. Bass. 1995. Forum Protestant, Catholic, Jew: The Transformative Possibilities of Educating Across Religious Boundaries. Religious Education 9: 254-76. [CrossRef]

Browning, Robert. 1990. Befriending the World: Beyond Interfaith Dialogue to Action. Religious Education 85: 331-45. [CrossRef]

Buckley, Francis J. 1991. Future Trends in Religious Education. Religious Education 86: 377-82. [CrossRef]

Buckley, Francis J. n.d. Maria de la Cruz Aymes. Christian Educators of the 20th Century. Available online: https:/ / www.biola.edu/talbot/ce20/database/maria-de-la-cruz-aymes (accessed on 15 June 2018).

Caldwell, Elizabeth F. 2011. God's Big Table: Nurturing Children in a Diverse World. Cleveland: Pilgrim Press. ISBN 9780829818147.

Case, Adelaide Teague. 1924. Liberal Christianity and Religious Education. New York: Macmillan.

Chave, Ernest J. 1944. Today and Tomorrow in Religious Education. Religious Education 39: 225-28. [CrossRef]

Chave, Ernest J. 1947. A Functional Approach to Religious Education. Chicago: University of Chicago Press.

Chave, Ernest J. 1950. Creative Curriculum Construction for moral and religious education. Religious Education 45: 152-58. [CrossRef]

Coe, George Albert. 1910. The President's Annual Address: New Reasons for Old Duties. Religious Education 5: 1-5. [CrossRef]

Coe, George Albert. 1916. The Psychology of Religion. Chicago: University of Chicago Press. ISBN 9781417904662.

Coe, George Albert. 1919. A Social Theory of Religious Education. New York: Charles Scribner's Sons.

Coe, George Albert. 1944. The Religious-Education Movement-A Retrospect. Religious Education 39: 220-24. [CrossRef]

Coe, George Albert, and Reinhold Niebuhr. 1933. Coe vs. Niebuhr. The Christian Century, March 15, 362-64.

Court, Deborah, and Jack L. Seymour. 2015. What Might Meaningful Interfaith Education Look Like: Exploring Politics, Principles, Pedagogy. Religious Education 110: 517-33. [CrossRef]

Crain, Margaret Ann, and Jack L. Seymour. 2003. Yearning for God: Reflections of Faithful Lives. Nashville: Upper Room Books.

Crawford, Marisa, and Graham Rossiter. 2006. Reasons for Living: Education and Young People's Search for Meaning, Identity and Spirituality. A Handbook. Camberwell: ACER. ISBN 100864316135.

Davis, Orville L. 1949. A History of the Religious Education Association. Religious Education 44: 41-54. [CrossRef] 
Elias, John. 2004. Catholics in the REA, 1903-1953. Religious Education 99: 225-46. [CrossRef]

Elias, John, and Sharan B. Merriam. 2005. Philosophical Foundations of Adult Education, 3rd ed. Malabar: Krieger. ISBN 9781575242545.

Elkind, David. 1970. The Origins of Religion in the Child. Review of Religious Research 12: 35-42. [CrossRef]

Elliot, Harrison S. 1940. Can Religious Education Be Christian? New York: Macmillan.

Elliott, Harrison S. 1950. Reflections of a Religious Educator. Religious Education 45: 195-202. [CrossRef]

English, Leona M. 1998. Mentoring in Religious Education. Birmingham: Religious Education Press. ISBN 0891351078.

Erikson, Erik. 1985. Childhood and Society 35th Anniversary Edition. New York: W. W. Norton. ISBN 0393303881. First published in 1963.

Fahs, Sophia Lyon. 1952. Today's Children and Yesterday's Heritage: A Philosophy of Creative Religious Development. Boston: Beacon.

Fahs, Sophia Lyon. 1971. The Future and Religious Education. Religious Education 66: 457-59. [CrossRef]

Fleischer, Barbara J. 2000. Practical Theology and Transformative Learning: Partnership for Christian Religious Education. In Forging a Better Religious Education in the Third Millennium. Edited by James Michael Lee. Birmingham: Religious Education Press, pp. 203-25. ISBN 0891351132.

Fletcher, Catherine. 1968. New Frontiers in Ethical and Religious Education. Religious Education 63: 107-11. [CrossRef]

Foster, Charles R. 2006. Educating Congregations: The Future of Christian Education. Nashville: Abingdon. ISBN 9780687002450. First published in 1994.

Foster, Charles R. 2012. From Generation to Generation: The Adaptive Challenge of Mainline Protestant Education in Forming Faith. Eugene, OR: Cascade Books. ISBN 139781620321959.

Foster, Charles R. 2015. Educating American Protestant Religious Educators. Religious Education 110: 545-54. [CrossRef]

Fowler, James W. 1981. Stages of Faith: The Psychology of Human Development and the Quest for Meaning. San Francisco: Harper and Row.

Freire, Paulo. 2018. Pedagogy of the Oppressed. 50th Anniversary Edition ed. New York: Bloomsbury Academic. ISBN 1501314130.

Gaebelein, Frank E. 1951. Christian Education in a Democracy. New York: Oxford University Press.

Gangel, Kenneth O. 1983. Toward a Harmony of Faith and Learning: Essay on Bible College Curriculum. Farmington Hills: William Tyndale College Press.

Gilligan, Carol. 2003. In a Different Voice: Psychological Theory and Women's Development, Thirty-Eighth Printing. Cambridge: Harvard University Press. ISBN 0674970969.

Gilmour, Peter. 2015. Educating the Educators: A Fifty-Year Retrospective of Religious Education in the Catholic Context. Religious Education 110: 555-68. [CrossRef]

Goldman, Ronald. 1968. Religious Thinking from Childhood to Adolescence. New York: Seabury Press. First published in 1964.

Goldman, Ronald. 1970. Readiness for Religion: A Basis for Developmental Religious Education. New York: Seabury Press.

Greene, Maxine. 1995. Releasing the Imagination: Essays on Education, the Arts, and Social Change. San Francisco: Jossey-Bass.

Groome, Thomas H. 1980. Christian Religious Education: Sharing our Story and Vision. San Francisco: Harper and Row. ISBN 006063491X.

Groome, Thomas H. 1987. Theology on our Feet: A Revisionist Pedagogy for Healing the Gap between Academia and Ecclesia. In Formation and Reflection: The Promise of Practical Theology. Edited by Lewis S. Mudge and James N. Poling. Philadelphia: Fortress Press, pp. 55-78.

Groome, Thomas H. 2011. Will There Be Faith? A New Vision for Educating and Growing Disciples. New York: HarperCollins. ISBN 9780062037282.

Groome, Thomas H., and Harold Daly Horell. 2003. Horizons E Hopes: The Future of Religious Education. Mahwah: Paulist. ISBN 080914154X.

Gunn, Dennis. 2018. From pan-Protestantism to pluralism: Herman Wornom and the REA's Journey Toward Ecumenical and Interreligious Encounter, 1952-1970. Religious Education. [CrossRef] 
Halsall, Anna, and Bert Roebben. 2006. Intercultural and Interfaith Dialogue through Education. Religious Education 101: 443-52. [CrossRef]

Harris, Maria. 1987. Teaching and Religious Imagination. San Francisco: Harper and Row. ISBN 0062548018.

Harris, Maria. 1989. Fashion Me a People: Curriculum in the Church. Louisville: Westminster/John Knox Press. ISBN 0664240526.

Harris, Maria, and Gabriel Moran. 1998. Reshaping Religious Education: Conversations on Contemporary Practice. Louisville: Westminster John Knox. ISBN 0664257836.

Hartshorne, Hugh. 1933. What is Religious Education For? Religious Education 28: 277-83. [CrossRef]

Havighurst, Robert J. 1984. Human Development and Education. New York: Longmans, Green.

Homrighausen, Elmer. 1936. Christianity in America: A Crisis. New York: Abingdon Press.

Homrighausen, Elmer. 1939. The Real Problem of Religious Education. Religious Education 34: 10-17. [CrossRef]

Hooks, Bell. 1994. Teaching to Transgress: Education as the Practice of Freedom. New York: Routledge.

Horell, Harold Daly. n.d. Thomas H. Groome. Christian Educators of the 20th Century. Available online: https: / / www.biola.edu/talbot/ce20/database/thomas-groome (accessed on 15 June 2018).

Hull, John, ed. 1982. New Directions in Religious Education. Lewes: Falmer Press. ISBN 978-0-905273-30-3.

Hull, John. 2003. Some Guidelines for the Future Development of Religious Education. Education and Ecumenical Formation: World Council of Churches 12: 7-9.

ISREV. n.d. Who We Are. York St. John University. Available online: https://www.yorksj.ac.uk/isrev/who-weare- / (accessed on 21 October 2018).

Jackson, Robert. 1997. Religious Education: An Interpretive Approach. London: Hodder and Stoughton. ISBN 97803400688700.

Johnson, Paul. 1976. A History of Christianity. New York: Simon and Shuster. ISBN 0684815036.

Kathan, Boardman W. n.d. Luther Allan Weigle. Christian Educators of the 20th Century. Available online: https: / / www.biola.edu/talbot/ce20/database/luther-allan-weigle (accessed on 1 June 2018).

Kegan, Robert. 1982. The Evolving Self: Problem and Process in Human Development. Cambridge: Harvard University Press. ISBN 0674272307.

Kegan, Robert. 1994. In Over Our Heads: The Mental Demands of Modern Life. Cambridge: Harvard University Press. ISBN 0674445872.

King, Henry Churchill. 1909. The Future of Moral and Religious Education. Religious Education 4: $293-303$. [CrossRef]

Kohlberg, Lawrence. 1981. The Philosophy of Moral Development: Moral Stages and the Idea of Justice. San Francisco: Harper and Row. ISBN 0060647604.

Lawson, Kevin E. 2003. Marginalization and Renewal: Evangelical Christian Education in the Twentieth Century. Religious Education 98: 437-53. [CrossRef]

Lawson, Kevin E., ed. 2012. Understanding Children's Spirituality: Theology, Research, and Practice. Eugene: Cascade. ISBN 9781610975254.

Lee, James Michael, ed. 1971. The Shape of Religious Instruction. Mishawaka: Religious Education Press. ISBN 9780891350026.

Lee, James Michael, ed. 1973. The Flow of Religious Instruction. Birmingham: Religious Education Press. ISBN 9780891350033.

Lee, James Michael, ed. 1985. The Content of Religious Instruction. Birmingham: Religious Education Press. ISBN 0891350500.

Lee, James Michael, ed. 2000. Forging a Better Religious Education in the Third Millennium. Birmingham: Religious Education Press. ISBN 0891351132.

Lee, Boyung. 2013. Transforming Congregations through Community: Faith Formation from the Seminary to the Church. Louisville: Westminster John Knox.

Le Tran, Mai-Anh. 2011. Diferente Desde Aquí: Twenty-Four Ways of Looking at Religious Education. Religious Education 106: 147-61. [CrossRef]

Levine, Daniel U., and Robert J. Havighurst. 1984. Society and Education, 6th ed. Boston: Allyn and Bacon. ISBN 0205080847.

Litchfield, Randy G. 2006. Research for a Movement. Religious Education 101: 165-62. [CrossRef]

Little, Sarah. 1983. To Set One's Heart: Belief and Teaching in the Church. Atlanta: John Knox. ISBN 0804214425. 
Loder, James. 1981. The Transforming Moment: Understanding Convictional Experiences. San Francisco: Harper and Row. ISBN 0060652764.

Loder, James. 1998. The Logic of the Spirit: Human Development in Theological Perspective. San Francisco: Jossey-Bass. ISBN 078790919X.

Lynn, Robert W., and Elliott Wright. 1980. The Big Little School: Two Hundred Years of the Sunday School. 2nd ed. rev. and enl. Birmingham: Religious Education Press. ISBN 0891350217.

McKibben, Frank M. 1939. Trends in Progressive Religious Education. Religious Education 34: 131-34. [CrossRef]

Melchert, Charles F. 1998. Wise Teaching: Biblical Wisdom and Educational Ministry. Harrisburg: Trinity Press International. ISBN 9781563381393.

Melchert, Charles F., and Randy Litchfield. n.d. Association of Professors and Researchers in Religious Education. Religious Education Association. Available online: https://religiouseducation.net/history/aboutaprre (accessed on 1 June 2018).

Miller, Randolph Crump. 1950. The Clue to Christian Education. New York: Charles Scribner's Sons.

Miller, Randolph Crump. 1977. Theology and the Future of Religious Education. Religious Education 72: 46-60. [CrossRef]

Miller, Randolph Crump. 1989. The Problem of Evil and Religious Education. Religious Education 84: 5-15. [CrossRef]

Miller, Randolph Crump. 1991. Children and Ethics. Religious Education 86: 134-44. [CrossRef]

Moore, Mary Elizabeth Mullino. 1983. Teaching from the Heart: Theology and Educational Method. Harrisburg: Trinity Press International. ISBN 9781563382536.

Moore, Allen J. 1989. Religious Education as Social Transformation. Birmingham: Religious Education Press. ISBN 0891350691.

Moore, Mary Elizabeth Mullino. 1998. Education for Continuity and Change: A New Model for Christian Religious Education. Nashville: Abingdon. ISBN 068711523X.

Moore, Allen J. 2003. One Hundred Years of the Religious Education Association. Religious Education 98: 426-36. [CrossRef]

Moore, Mary Elizabeth Mullino, and Almeda M. Wright, eds. 2008. Children, Youth, and Spirituality in a Troubled World. Danvers: Chalice Press. ISBN 9780827205130.

Moran, Gabriel. 1989. Religious Education as a Second Language. Birmingham: Religious Education Press. ISBN 0891350721.

Moran, Gabriel. 1996. A Grammar of Responsibility. New York: Crossroad. ISBN 0824515544.

Moran, Gabriel. 2000. Building on the Past. In Forging a Better Religious Education in the Third Millennium. Edited by James Michael Lee. Birmingham: Religious Education Press, pp. 134-54. ISBN 0891351132.

Nelson, C. Ellis. 1967. Where Faith Begins. Richmond: John Knox.

Nelson, C. Ellis. 1983. Toward Accountable Selfhood. In Modern Masters of Religious Education. Edited by Marlene Mayr. Birmingham: Religious Education Press, pp. 260-173.

Nelson, C. Ellis. 1984. Toward the Year 2003. Religious Education 78: 101-7. [CrossRef]

Ng, David. 1992. Working with Pacific Asian American Families. In Faith and Families: A Parish Program for Parenting in Faith Growth. Edited by Thomas Bright and John Roberto. New Rochelle: Catholic Family Services.

Niebuhr, Reinhold. 1932. Moral Man and Immoral Society: A Study in Ethics and Politics. New York: Scribner. ISBN 1425496016.

O'Brien, Maureen. 2010. Practicing in the Presence of Mystery: Responses to the Divine in Practical Theology and Religious Education. Religious Education 105: 358-72. [CrossRef]

O'Gorman, Robert T. 2015. The Center of Religious Education: Will it Hold? Religious Education 110: 487-90. [CrossRef]

O'Hare, Padraic, ed. 1983. Education for Peace and Justice. San Francisco: Harper and Row. ISBN 0060663618.

O'Hare, Padraic. 1993. The Way of Faithfulness. Contemplation and Formation in the Church. ISBN 1563380668.

Oser, Fritz, and Paul Gmünder. 1991. Religious Judgment: A Developmental Approach. Translated by Norbert F. Hahn. Birmingham: Religious Education Press. ISBN 0891350810.

Osmer, Richard Robert. 2000. A New Clue for Religious Education in a New Millennium? Cross-Disciplinary Thinking at the Turn of the Millennium. In Forging a Better Religious Education in the Third Millennium. Edited by James Michael Lee. Birmingham: Religious Education Press, pp. 179-202. ISBN 0891351132. 
Osmer, Richard Robert. 2005. The Teaching Ministry of Congregations. Louisville: Westminster John Knox. ISBN 0664225470.

Osmer, Richard R., and Friedrich Schweitzer. 2003. Religious Education between Modernization and Globalization. Grand Rapids, MI: Eerdmans. ISBN 0802812848.

Ostrander, Rick. 2009. Why College Matters to God: An Introduction to the Christian College, 2nd ed. Aniline: Abilene Christian University Press. ISBN 9780891123231.

Parent, Neil. 2009. A Concise Guide to Adult Faith Formation. Notre Dame: Ave Maria Press. ISBN 101594712085.

Parker, Evelyn L. 2006. The Sacred Selves of Adolescent Girls: Hard Stories of Race, Class, and Gender. Cleveland: Pilgrim. ISBN 0829816887.

Pazmiño, Robert W. 2008. Foundational Issues in Christian Education: An Introduction in Evangelical Perspective, 3rd ed. Grand Rapids: Baker Books. ISBN 9780801035937.

Prevost, Ronnie. 1998. The Prophetic Voice of the Religious Educator: Past, Present, and Future. Religious Education 93: 288-306. [CrossRef]

REA. 1903. Proceedings of the First Annual Convention, Chicago, February 10-12, 1903. Chicago: Executive Office of the Association.

REA a. n.d. Design for a Joint Reorganization of APRRE and REA. Religious Education Association. Available online: https:/ / religiouseducation.net/wp-content/uploads/2011/02/REA_APRRE_052003.pdf (accessed on 1 June 2018).

REA Archives. n.d. REA Archives, RG 74A. New Haven: Special Collections, Yale Divinity School Library.

REA b. n.d. Officials of REA and APRRE. Religious Education Association. Available online: https:// religiouseducation.net/wp-content/uploads/2011/02/History-OFFICIALS-REA-APRRE.pdf (accessed on 1 June 2018).

REA c. n.d. Work Groups. Religious Education Association. Available online: https://religiouseducation.net/ workgroups (accessed on 1 June 2018).

Regan, Jane. 2002. Toward an Adult Church: A Vision of Faith Formation. Chicago: Loyola Press. ISBN 0829418067.

Richardson, Norman Egbert. 1931. The Christ of the Classroom: How to Teach Evangelical Christianity. New York: Macmillan.

Robinson, Edward. 1983. The Original Vision: A Study of the Religious Experience of Childhood. New York: Seabury Press. ISBN 10081642439X.

Schipani, Daniel S. 1988. Religious Education Encounters Liberation Theology. Birmingham: Religious Education Press. ISBN 0891350594.

Schmidt, Stephen A. 1983. A History of the Religious Education Association. Birmingham: Religious Education Press. Scott, Kieran. 1984. Three Traditions of Religious Education. Religious Education 79: 327-39. [CrossRef]

Selçuk, Mualla. 2018. Crossroads, Connections, Collaborations. Religious Education. [CrossRef]

Seymour, Jack L. 2005. Religious Education and the Future of Religious Education. Religious Education 100: 337-39. [CrossRef]

Seymour, Jack L., Robert T. O'Gorman, and Charles R. Foster. 1984. The Church in the Education of the Public. Nashville: Abingdon. ISBN 06870825528.

Seymour, Jack L., Margaret Ann Crain, and Joseph V. Crocket. 1993. The Intersection of Meaning, Learning, and Vocation. Nashville: Abingdon. ISBN 0687096278.

Sherrill, Lewis Joseph. 1951. The Struggle of the Soul. New York: Macmillan.

Sherrill, Lewis Joseph. 1955. The Gift of Power. New York: Macmillan.

Smart, James D. 1954. The Teaching Ministry of the Church: An Examination of Basic Principles of Christian Education. Philadelphia: Westminster Press.

Smith, H. Shelton. 1941. Faith and Nurture. New York: Charles Scribner's Sons.

Smith, H. Shelton. 1942-1943. The Supremacy of Christ in Christian Nurture. Religion in Life 12: 31-40.

Smith, W. Alan. n.d. George Herbert Betts. Christian Educators of the 20th Century. Available online: https: / / www.biola.edu/talbot/ce20/database/george-herbert-betts (accessed on 1 June 2018).

Smith, Yolanda Y. n.d. Anne Streaty Wimberly. Christian Educators of the 20th Century. Available online: https: / / www.biola.edu/talbot/ce20/database/anne-streaty-wimberly (accessed on 1 June 2018).

Spiro, Jack D. 1984. The Future of Religious Education: Personal Reflections. Religious Education 79: 96-101. [CrossRef] 
Starbuck, Edwin Diller. 1909. Moral and Religious Education- Sociological Approach. Religious Education 3: $203-17$. [CrossRef]

Strommen, Merton P., ed. 1971. Research on Religious Development, A Comprehensive Handbook: A Project of the Religious Education Association. New York: Hawthorne.

Strommen, Merton P., and Richard A. Hardel. 2000. Passing on the Faith: A Radical New Model for Youth and Family Ministry. Winona: St. Mary's Press, Christian Brothers Publications. ISBN 9780884899709.

Tauber, Sarah M. 2015. Open Minds, Devoted Hearts: Portraits of Adult Religious Educators. Eugene: Pickwick. ISBN 978149818764.

Ten Boom, Corrie. 2009. The Hiding Place. Peabody: Hendrickson. ISBN 978-1-59856-339-9. First published in 2006.

Tracy, Frederick, Francis Greenwood Peabody, J. W. F. Davies, Henry Churchill King, Herbert Wright Gates, Kenyon L. Butterfield, Hugh Hartshorn, Benjamin S. Winchester, William I. Lawrance, Edward Porter St. John, and et al. 1917. Ideals and Methods of Religious Education for the Coming World Order. Religious Education 12: 181-95. [CrossRef]

Tye, Karen B. 2000. Basics of Christian Education. St. Louis: Chalice Press. ISBN 97808227202290.

United States Conference of Catholic Bishops (USCCB). 2008. Doctrinal Elements of a Curriculum Framework for the Development of Catechetical Materials for Young People of High School Age. Washington, DC: USCCB. ISBN 9781601370426.

Veverka, Fayette. n.d. Francoise Darcy-Berube. Christian Educators of the 20th Century. Available online: https: / www.biola.edu/talbot/ce20/database/francoise-darcy-berube (accessed on 15 June 2018).

Vieth, Paul H. 1964. Religious Education Faces the Future. Religious Education 59. [CrossRef]

Votaw, Clyde W. 1905. The Field of Religious Education in America. The Biblical World 25: 347-60. [CrossRef]

Weigle, Luther Allan. 1911. The Pupil and the Teacher. New York: Hodder and Stoughton.

Wimberly, Anne Streaty. 2005. Soul Stories: African American Christian Education, Rev. ed. Nashville: Abingdon. ISBN 068749432X.

Wyckoff, DeWitte Campbell. 1961. Theory and Design of Christian Education Curriculum. Philadelphia: Westminster Press.

Yust, Karen Maria, Aostre N. Johnson, Sandy Eisenberg Sasso, and Eugene C. Roehlklepartain, eds. 2005. Nurturing Child and Adolescent Spirituality: Perspectives from the World's Religious Traditions. Lanham: Roman and Littlefield. ISBN 0742544621.

(C) 2018 by the author. Licensee MDPI, Basel, Switzerland. This article is an open access article distributed under the terms and conditions of the Creative Commons Attribution (CC BY) license (http://creativecommons.org/licenses/by/4.0/). 